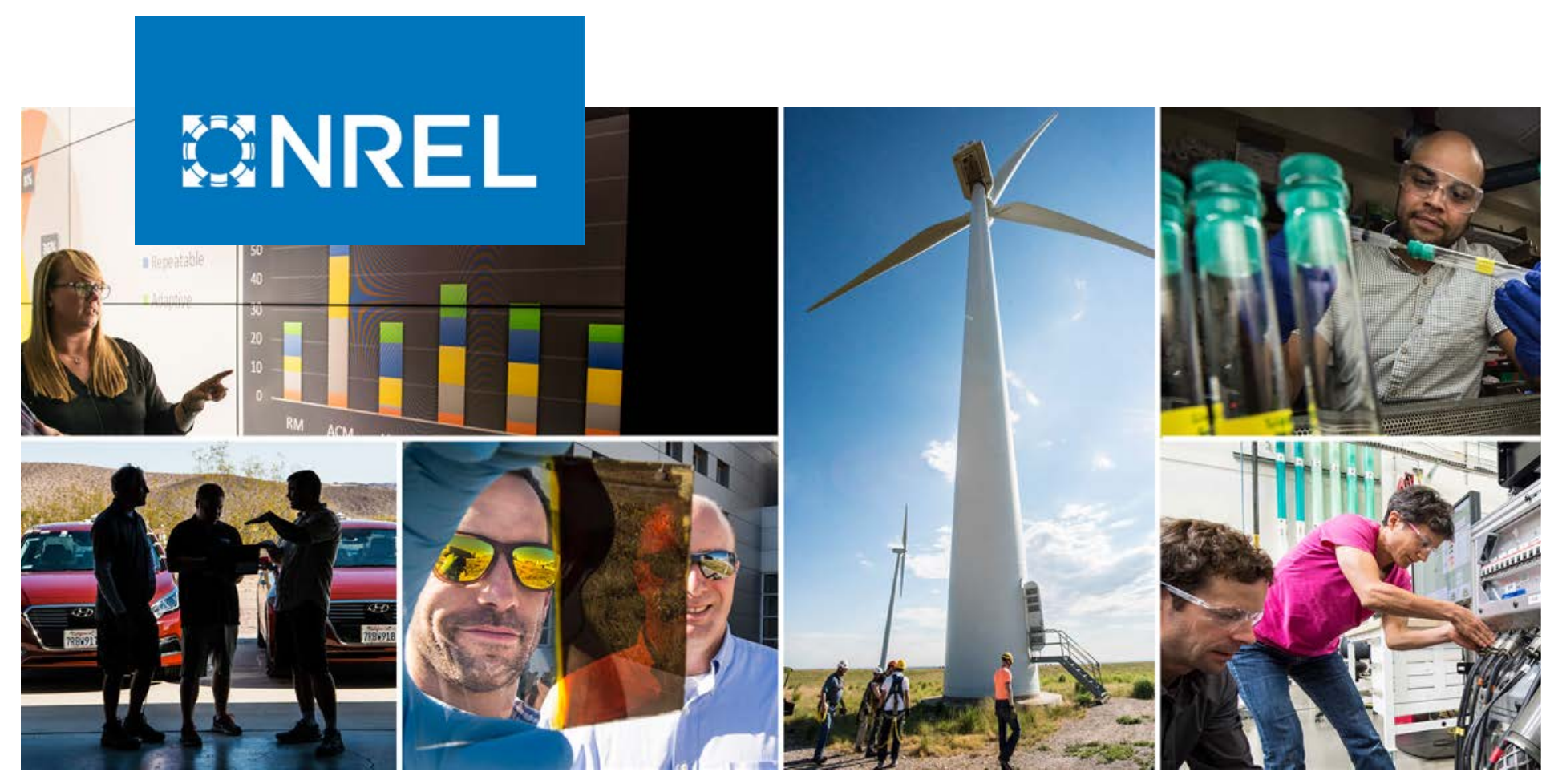

\title{
An Overview of Policies Influencing Air Pollution from the Electricity Sector in South Asia
}

\author{
J. Erik Ness, Vikram Ravi and Garvin Heath
}

National Renewable Energy Laboratory

Produced under direction of the U.S. Department of State's Bureau of

Energy Resources by the National Renewable Energy Laboratory (NREL) under Interagency Agreement no. IA-1931BH17Y0001.

NREL is a national laboratory of the U.S. Department of Energy Office of Energy Efficiency \& Renewable Energy

Operated by the Alliance for Sustainable Energy, LLC

This report is available at no cost from the National Renewable Energy Laboratory (NREL) at www.nrel.gov/publications.
Strategic Partnership Project Report NREL/TP-7A40-80156

August 2021 


\section{FANEL}

\section{An Overview of Policies Influencing Air Pollution from the Electricity Sector in South Asia}

J. Erik Ness, Vikram Ravi and Garvin Heath

National Renewable Energy Laboratory

\section{Suggested Citation}

Ness, J. Erik, Vikram Ravi, and Garvin Heath. 2021. An Overview of Policies Influencing Air Pollution from the Electricity Sector in South Asia. Golden, CO: National Renewable Energy Laboratory. NREL/TP-7A40-80156. https://www.nrel.gov/docs/fy21osti/80156.pdf.

NREL is a national laboratory of the U.S. Department of Energy Office of Energy Efficiency \& Renewable Energy Operated by the Alliance for Sustainable Energy, LLC

This report is available at no cost from the National Renewable Energy Laboratory (NREL) at www.nrel.gov/publications.

Contract No. DE-AC36-08GO28308
Strategic Partnership Project Report NREL/TP-7A40-80156 August 2021

National Renewable Energy Laboratory 15013 Denver West Parkway Golden, CO 80401 303-275-3000 • www.nrel.gov 


\section{NOTICE}

This work was authored by the National Renewable Energy Laboratory, operated by Alliance for Sustainable Energy, LLC, for the U.S. Department of Energy (DOE) under Contract No. DE-AC36-08GO28308. Support for the work was also provided by the U.S. Department of State's Bureau of Energy Resources under Inter-Agency Agreement no. IAA-1931BH17Y0001. The views expressed in the article do not necessarily represent the views of the DOE or the U.S. Government. The U.S. Government retains and the publisher, by accepting the article for publication, acknowledges that the U.S. Government retains a nonexclusive, paid-up, irrevocable, worldwide license to publish or reproduce the published form of this work, or allow others to do so, for U.S. Government purposes.

This report is available at no cost from the National Renewable Energy Laboratory (NREL) at www.nrel.gov/publications.

U.S. Department of Energy (DOE) reports produced after 1991 and a growing number of pre-1991 documents are available free via www.OSTI.gov.

Cover Photos by Dennis Schroeder: (clockwise, left to right) NREL 51934, NREL 45897, NREL 42160, NREL 45891, NREL 48097, NREL 46526.

NREL prints on paper that contains recycled content. 


\section{Acknowledgments}

The authors would like to thank Mark Pituch at the U.S. Department of State's Bureau of Energy Resources for his vision in both commissioning and guiding this research project.

The authors would also like to acknowledge the review input provided by other Department of State and USAID staff, including:

- Lanta V. Spencer, Kabul, Afghanistan

- Shayan Shafi, Acting Deputy Director, Economic Growth Office, USAID Bangladesh

- Anne N. Sherman, Dhaka, Bangladesh

- Shanker Khagi, Environment and Energy Specialist, USAID, U.S. Embassy, Kathmandu, Nepal

- Michelle Lorenzo, Kathmandu, Nepal

- Donald McCubbin, Acting Director, Office of Energy, USAID, U.S. Embassy, Islamabad, Pakistan

- Anne Sackville-West, Energy Officer, U.S. Embassy, Islamabad, Pakistan

- Luis G. Salas, Colombo, Sri Lanka.

In addition, the authors benefited from research assistance and reviews provided by the following in-country contacts:

- Christopher M. Wilkinson, Lieutenant Colonel, U.S. Army; Chief, Programs and Analysis, Kabul, Afghanistan

- Dr. Abdullah Al Mamun, Deputy Director, Department of Environment, Ministry of Environment, Forest and Climate Change, Bangladesh.

The following staff at the National Renewable Energy Laboratory also made important contributions to this report through their guidance, review input, and research: David Palchak, Edward Settle, Jason Youngstrom, Ilya Chernyakhovskiy, and Daniel Bennett. 


\section{List of Acronyms}

\begin{tabular}{|c|c|}
\hline ADB & Asian Development Bank \\
\hline BIMSTEC & Bay of Bengal Initiative for Multi-Sectoral Technical and Economic Cooperation \\
\hline CASA-1000 & Central Asia-South Asia (transmission project) \\
\hline CBET & cross-border electricity trade \\
\hline CEMS & continuous emissions monitoring system \\
\hline $\mathrm{CHP}$ & combined heat and power \\
\hline $\mathrm{CO}$ & carbon monoxide \\
\hline COPD & chronic obstructive pulmonary disease \\
\hline CPEC & China Pakistan Economic Corridor \\
\hline DG & distributed generation \\
\hline $\mathrm{DHC}$ & district heating and cooling \\
\hline DHP & district heating and cooling \\
\hline ESP & electrostatic precipitator \\
\hline EPA & U.S. Environmental Protection Agency \\
\hline ESCO & energy service company \\
\hline FGD & flue gas desulfurization \\
\hline FIT & feed-in tariff \\
\hline GDP & gross domestic product \\
\hline GHG & greenhouse gas \\
\hline GW & gigawatt \\
\hline INDC & intended nationally determined contribution \\
\hline LNG & liquefied natural gas \\
\hline LPG & liquified petroleum gas \\
\hline MW & megawatts \\
\hline NDC & nationally determined contribution \\
\hline NAAQS & national ambient air quality standards \\
\hline $\mathrm{NOx}$ & oxides of nitrogen \\
\hline PM & particulate matter (e.g., $\mathrm{PM}_{2.5}$, which has an aerodynamic diameter of $2.5 \mu \mathrm{m}$ ) \\
\hline PPA & power purchase agreement \\
\hline ppm & parts per million \\
\hline $\mathrm{PV}(\mathrm{s})$ & photovoltaic(s) \\
\hline REC & renewable energy credit \\
\hline RES & renewable electricity standard \\
\hline RPS & renewable portfolio standard \\
\hline SAARC & South Asian Association for Regional Cooperation \\
\hline $\mathrm{SARI} / \mathrm{EI}$ & South Asia Regional Initiative for Energy Integration \\
\hline SCR & selective catalytic reduction \\
\hline SNCR & selective noncatalytic reduction \\
\hline $\mathrm{SOx}$ & oxides of sulfur \\
\hline T\&D & transmission and distribution \\
\hline TUTAP & Turkmenistan, Uzbekistan, Tajikistan, Afghanistan, and Pakistan \\
\hline U.S. & United States \\
\hline USAID & U.S. Agency for International Development \\
\hline VOC & volatile organic compound \\
\hline VRE & variable renewable energy \\
\hline
\end{tabular}




\section{Abstract}

The electricity (power generation) sector is a substantial source of air pollution and associated health problems in South Asia and elsewhere. Fossil-fueled power plants emit a wide variety of harmful pollutants. The pollutants with the greatest health impacts are particulate matter and ozone. Once released into the atmosphere, there is no practical way to remove air pollutants, which means that policies designed to improve air quality have to limit the pollutants before release. However, tackling such pollution is challenging, particularly in developing economies, due to the need to provide electricity as a basic necessity for their citizens and as an engine of economic growth.

This report provides examples of policies impacting air pollution from the fossil-fuel electricity sector in the South Asian countries of Afghanistan, Bangladesh, Bhutan, India, Maldives, Nepal, Pakistan, and Sri Lanka. Information on policies in some countries was difficult to locate; therefore, this is not a comprehensive study, but rather an overview or "scan" of the sector that includes examples of: (1) policies that directly regulate air quality by limiting emissions from specific point sources (by restricting operating hours, for instance); and (2) indirect policies that incentivize or disincentivize polluting activities, such as policies to encourage fuel switching to or from cleaner renewable resources, for example.

The report shows:

1. The great variation among the policy instruments used in each country

2. That many countries, especially those that have a mismatch between seasonal demand and resource availability, could improve energy security and reduce air pollution through increased cross-border electricity trade

3. Some countries have seemingly contradictory policies (promoting both coal and renewables, for instance). 


\section{Table of Contents}

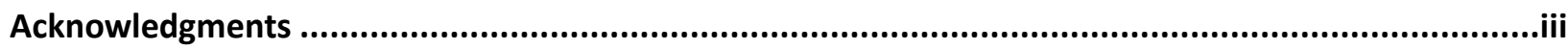

List of Acronyms

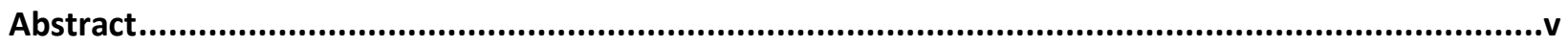

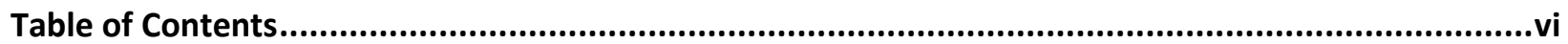

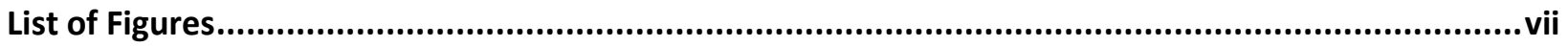

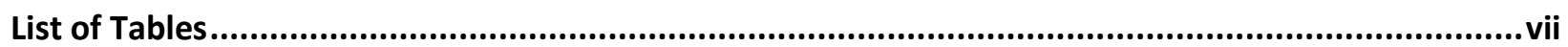

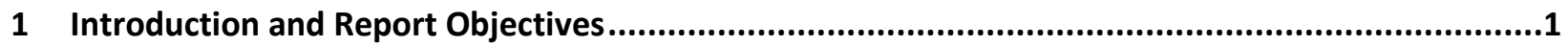

1.1 Types of Pollutants and Their Potential Impacts .............................................................................

1.2 Link Between Available Energy Resources and Air Quality Policies ....................................................

$1.3 \quad$ Emissions Standards and Policy Options for Limiting Air Pollutants....................................................

2 Air Quality Standards that Set Pollutant Limits ......................................................................

3 Direct Policies Intended to Reduce Air Pollution ...................................................................11

3.1 Removal of Fuel Contaminants Before Combustion ……..............................................................11

3.2 Combustion Process Modification To Reduce Emissions ....................................................................11

3.3 Post-Combustion Controls To Reduce Emissions ................................................................................12

3.4 More-Efficient Combustion Technologies To Reduce Fuel Consumption Per Unit of Energy Generated..13

3.5 Higher Stack Height To Improve Pollutant Dispersion ........................................................................13

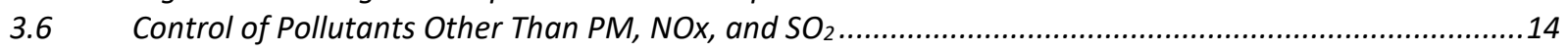

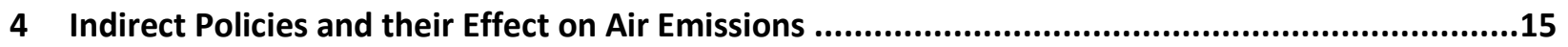

4.1 Policies and Regulations that Can Lead To Increased Emissions or Delay Emissions Reductions..............15

4.1.1 Mandates, Financial, and Other Incentives for Combustion-Based Generation and Fuels .................15

4.1.2 Constrained or Unavailable Cleaner Energy Resources .................................................................16

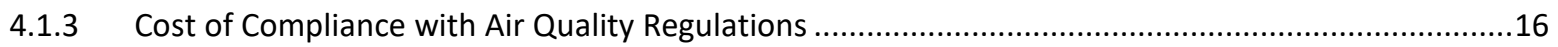

4.2 Policies and Regulations that Can Lead To Decreased Emissions......................................................16

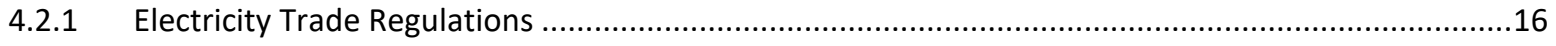

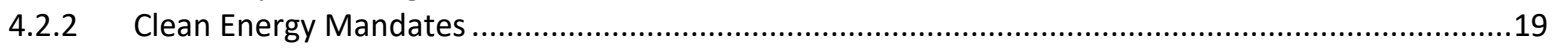

4.2.3 Financial and Other Incentives for Power Generation from Clean Energy ......................................20

4.2.4 Financial Disincentives for Combustion-Based Generation ..............................................................23

4.2.5 Energy Conservation, Energy Efficiency Mandates, and Improvements ..........................................24

4.2.6 Combined Heat and Power and District Heating/Cooling Requirements .........................................25

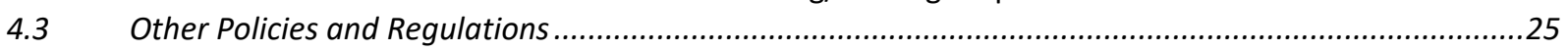

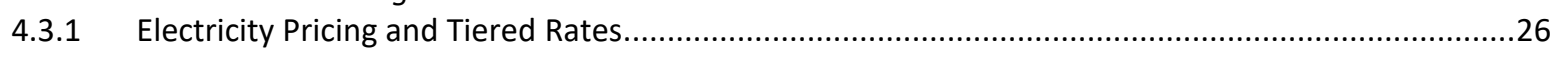

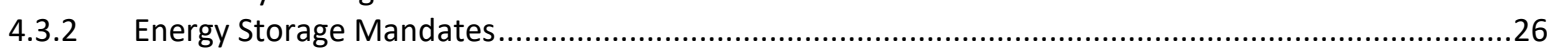

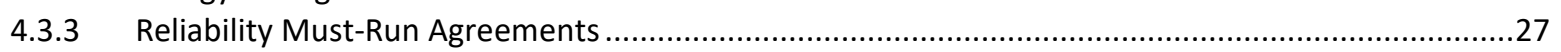

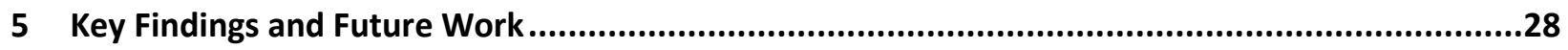

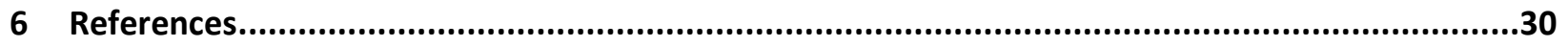

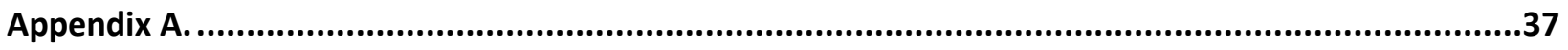

A.1 Brief Description of Emission Control Devices Referred To in this Report..............................................37

A.2 Emissions Standards Set by the Government of India in 2015.........................................................38 


\section{List of Figures}

Figure 1. PM2.5 mean annual exposure concentration by region (micrograms per cubic meter)

\section{List of Tables}

Table 1. Energy Resource Endowments in South Asian Countries ........................................................ 4

Table 2. Comparison of NAAQS for South Asian Countries ................................................................. 7

Table 3. Emission Standards for Coal, Oil, and Natural Gas-Fired Power Plants Enacted Through Various

Emissions Standard Regulations for 5 South Asian Countries ........................................... 8

Table 4. India's Policy on Cleaning Coal To Reduce Emissions ......................................................... 11

Table 5. Example Control Techniques Implemented for Combustion Process Modification To Reduce

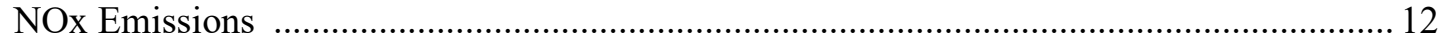

Table 6. Available Control Technologies To Reduce Post-Combustion Emissions................................... 13

Table 7. Prospects for Cross-Border Electricity Trade in South Asia .................................................... 18

Table 8. New Emission Standards for Power Plants Enacted through the Environment Protection

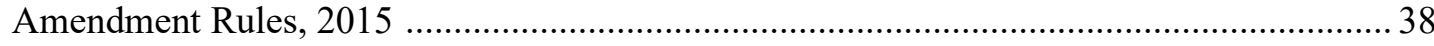

vii 


\section{Introduction and Report Objectives}

Power generation in most South Asian countries is currently heavily dominated by fossil fuels, ${ }^{1}$ but with the prospect on the horizon of accessing substantially untapped clean renewable resources. Until then, many of the existing fossil fuel power plants are a source of harmful air pollution that adversely affects human health. In 2016, 17 of the 30 cities with the world's poorest air quality were in South Asia $[69,72]$.

The U.S. Department of State commissioned this report as part of a broader effort to examine the connection between electricity production and air quality in the region, with the goal of highlighting areas where technical assistance and capacity building can support future policy development and implementation. For the purposes of this report, the South Asia region includes Afghanistan, Bangladesh, Bhutan, India, Maldives, Nepal, Pakistan, and Sri Lanka.

The scope of this initial investigation is to examine existing South Asian energy sector policies and regulations that could affect air pollution, focusing on the laws of central governments. It is not an exhaustive review. Rather, this report describes standards and policy instruments that are used in the region and gives some examples of South Asian countries that have those instruments. It is intended as a useful starting point for developing a more comprehensive record of all air quality policies in the countries and an analysis of their effectiveness, which are more substantial tasks beyond the scope of this initial scan. This report focuses on air pollution stemming from fossil fuel combustion in the electricity (power generation) sector. It does not address transportation, although that sector is also an important source of air pollution and may be the subject of a future study. It also does not address greenhouse gas (GHG) emissions and other climate-related impacts from emissions to the air from the power sector. GHG and nonGHG air pollutant emissions are related but not precisely correlated; analysis of GHG emission policies will be greatly aided by the policy scan provided herein, but it requires additional research.

Reducing harmful emissions (see Section 1.1) from the power sector is a substantial challenge in many South Asian countries because economic development is also a priority and can compete with clean air goals. There is substantial variation from one country to another in terms of both economic development and emissions standards.

As an example, Afghanistan is at a stage of development where it is mainly focused on being able to produce enough electricity to meet basic needs and drive economic growth. The country has only recently (2019-2020) issued air quality regulations and is also hampered by the fact that it has nine separate, islanded regional grids that are fed from different supply sources [22]. By contrast, India is much further along in the development of its electricity sector with a unified

\footnotetext{
${ }^{1}$ For example, coal-fired thermal power plants account for $54 \%$ of India's installed power generation capacity. And almost all of Bangladesh's electricity generation is from fossil fuels, with $62 \%$ from gas, $34 \%$ from furnace oil and diesel, and $1 \%$ from coal (although coal's contribution is expected to increase to $22 \%$ by 2021 and $40 \%$ by 2030 ) $[3,11]$.
} 
grid, international electricity trading, and relatively comprehensive air quality emissions standards.

Other challenges encountered in the preparation of this report:

- In many countries, the authors found no central record of policies, which made it difficult to establish if a policy addressing a particular issue exists.

- Policies and regulations may exist on paper but there is no straightforward way to find out if they are actually implemented.

- The project's focus on national-level policies misses the fact that in some countries most air quality policies are subnational.

While this report focuses on policies at the national/transnational levels, it should be noted that three countries in South Asia (Pakistan, India and Nepal) are federal republics, like the United States. This means that some policies cannot be set at the national level and are instead devolved to the legislatures in the subnational jurisdictions. In these cases, when the national government makes a policy commitment on the domestic or international stage without first having secured the support of the entire federation, it should be viewed as an aspirational policy until it is adopted by the states or provinces. A good example is Pakistan's 2030 renewable energy target, described in Section 4.3.2.

\subsection{Types of Pollutants and Their Potential Impacts}

A wide variety of pollutants are emitted from fossil-fueled power plants. The pollutants addressed in this report are a subset of those that constitute particulate matter (PM) ${ }^{2}$ or ozone $\left(\mathrm{O}_{3}\right.$, the primary constituent of photochemical smog) and their precursors: $\mathrm{PM}_{2.5}, \mathrm{PM}_{10}$, oxides of sulfur ( $\mathrm{SOx}$ ), oxides of nitrogen $(\mathrm{NOx})$, carbon monoxide $(\mathrm{CO})$, ammonia $\left(\mathrm{NH}_{3}\right)$, and volatile organic compounds (VOCs).

In the atmosphere, NOx and SOx are noxious alone and can also undergo physical and chemical transformation and convert to $\mathrm{PM}_{2.5}$. $\mathrm{PM}_{2.5}$ can penetrate deep into the lungs and bloodstream causing respiratory issues, lung cancer, cardiovascular problems, and strokes - and can also degrade physical infrastructure, mainly through corrosion of building exteriors. Ozone exacerbates respiratory problems in the short term; long-term exposure can cause chronic obstructive pulmonary disease (COPD), an inflammatory lung disease that obstructs airflow from the lungs. In $2017,31 \%$ of the world's ozone-related COPD deaths were in India [17].

Once released into the atmosphere, there is no practical way to remove air pollutants or slow the atmospheric reactions forming the two pollutants of greatest concern from a health standpoint: $\mathrm{PM}_{2.5}$ and ground-level ozone. Consequently, policies intended to positively impact air quality must be designed to mitigate air pollutants before release.

There is a dual concern in many countries with limiting GHG emissions and controlling emissions of other air pollutants that have been traditionally regulated for protecting public health. While some national strategies can reduce both GHG and non-GHG air pollutants, other

${ }^{2}$ Called PM2.5 and PM10 because they have aerodynamic diameters of $2.5 \mu \mathrm{m}$ and $10 \mu \mathrm{m}$, respectively. 
strategies achieve only one outcome (e.g., controlling fluorocarbons reduces the emission of these highly potent GHGs, but these chemicals do not have direct health effects).

According to the World Bank, South Asia had the highest regional levels of $\mathrm{PM}_{2.5}$ pollution in 2017 compared to other regions $^{3}$ (see Figure 1). Globally, the top 10 countries with the highest mean exposure to ambient air pollution include Nepal (more than double the world average) and India in South Asia [16].

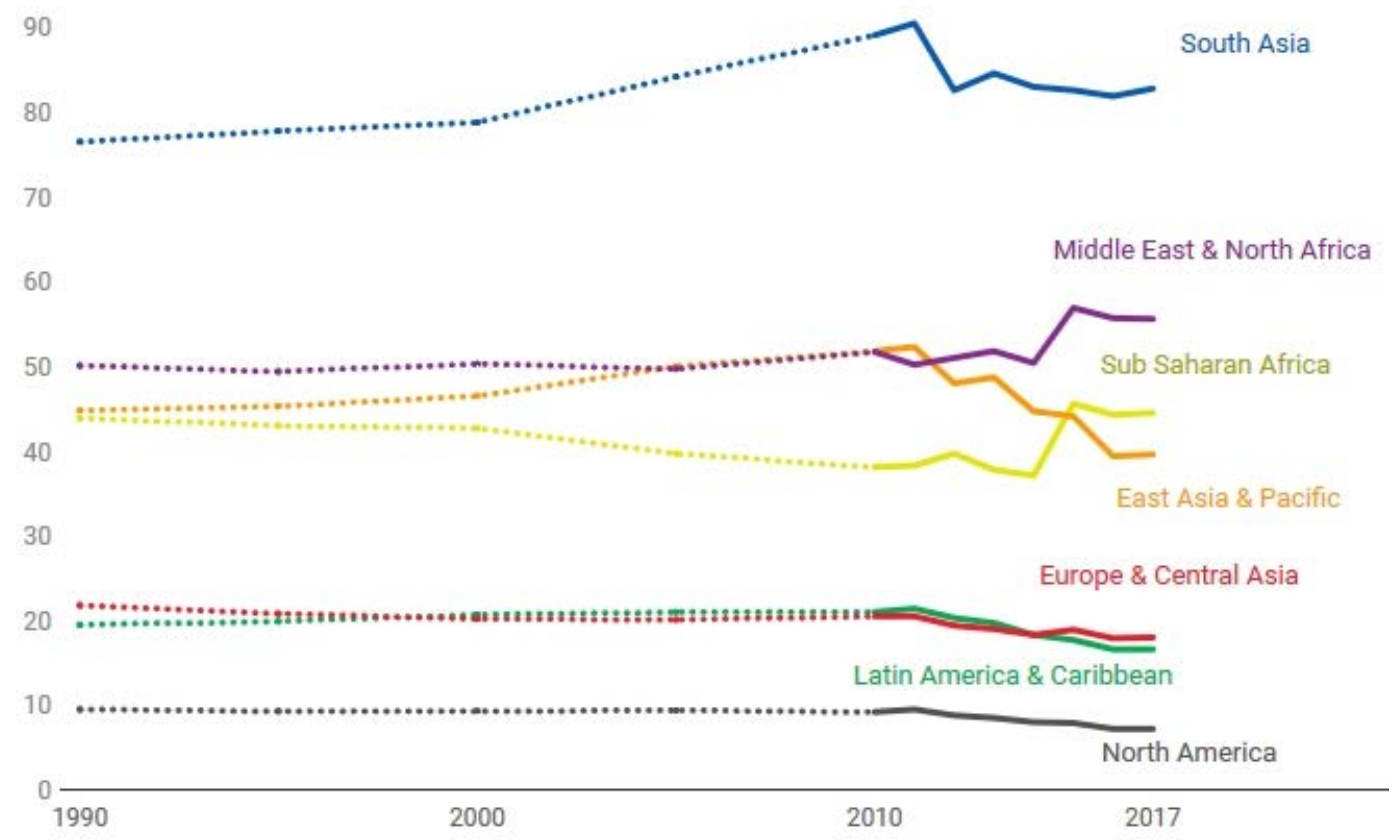

Figure 1. $\mathbf{P M}_{2.5}$ mean annual exposure concentration by region (micrograms per cubic meter) [16].

From 1990-2010, data is available at 5-year intervals. For intervening years, data points have been interpolated.

\subsection{Link Between Available Energy Resources and Air Quality Policies}

The South Asia region has extensive energy resources - both conventional and renewable-yet with substantial disparity in the distribution of these resources across the region. Table 1 shows the known resource capacity in each South Asian country, which may be a better indicator of future power generation than the current generation profile, given that each country is trying to pivot its domestic power system to take advantage of its indigenous resources.

Although there is some bilateral cross-border electricity trade today, electricity generation in each country is still heavily dependent on its own generating capacity and available domestic resources. The more fossil fuel in the energy mix used for power generation, the more air pollutants are likely to be emitted by power plants, and the greater the incentive countries have to put in place policies to curb emissions, if they are also concerned with the associated health

\footnotetext{
${ }^{3}$ The Republic of Maldives, an island chain located approximately 400 miles southwest of Sri Lanka, is a notable exception among countries in the South Asia region.
} 
effects. Whether such incentives are actually implemented or have any impact may depend on factors such as competing incentives, business interests, the existing energy infrastructure, and potential cost hurdles.

Bhutan and Nepal are almost completely dependent on Himalayan-fed hydropower resources, although Nepal is now also a net importer of electricity from India. Afghanistan is rebuilding its hydroelectric power capacity but currently imports much of its electricity from Central Asia [32]. Afghanistan's Herat province is actually on the Iranian power grid, which increases Afghanistan's dependence on Iran and vulnerability to Iranian political pressure [76].

Bangladesh, Maldives, and Sri Lanka are largely dependent on fossil fuels [32]. Bangladesh has historically used cleaner-burning natural gas plants, but its onshore gas reserves are declining and, until recently, the country was considering adding significant coal generation, with the expectation of associated higher emissions [33]. However, in February 2021, Bangladesh announced it is considering canceling plans for some of the new coal plants and also converting dozens of coal-fired power plants into liquefied natural gas (LNG) plants. The country has also expressed interest in developing renewable power [79]. Maldives is currently dependent on diesel generators, although it and Sri Lanka also have good wind and solar resources, and hydropower accounts for $28 \%$ of Sri Lanka's electricity generation [33, 23].

India and Pakistan depend on a combination of hydropower and fossil-fuel-based generation, though they are increasingly becoming more dependent on fossil fuels $[32,33]$.

Table 1. Energy Resource Endowments in South Asian Countries [32, 23]

("n/a" means the data is not available)

\begin{tabular}{|l|r|r|r|r|r|r|r|}
\hline $\begin{array}{l}\text { Country I } \\
\text { Resource }\end{array}$ & $\begin{array}{c}\text { Coal } \\
\text { (million } \\
\text { tonnes) }\end{array}$ & $\begin{array}{c}\text { Oil } \\
\text { (million } \\
\text { barrels) }\end{array}$ & $\begin{array}{c}\text { Natural } \\
\text { Gas } \\
\text { (trillion } \\
\text { cubic } \\
\text { feet) }\end{array}$ & $\begin{array}{c}\text { Biomass } \\
\text { (million } \\
\text { tonnes) }\end{array}$ & $\begin{array}{c}\text { Hydropower } \\
\text { megawatts } \\
\text { (MW) }\end{array}$ & $\begin{array}{c}\text { Solar } \\
\text { Energy } \\
\text { (kWh/sq. } \mathrm{m} \\
\text { per day) }\end{array}$ & $\begin{array}{c}\text { Wind } \\
\text { Power } \\
\text { megawatts } \\
\text { (MW) }\end{array}$ \\
\hline Afghanistan & 440 & $\mathrm{n} / \mathrm{a}$ & 15 & $18-27$ & 25,000 & $\mathrm{n} / \mathrm{a}^{\mathrm{b}}$ & $\mathrm{n}^{\mathrm{b}}{ }^{\mathrm{b}}$ \\
\hline Bhutan & 2 & 0 & 0 & 27 & 30,000 & $2.5-5$ & 4,825 \\
\hline Bangladesh & 884 & 12 & 8 & 0.08 & 330 & $3.8-6.5$ & very low \\
\hline India & 90,085 & 5,700 & 39 & 139 & 150,000 & $4-7$ & 151,918 \\
\hline Maldives & 0 & 0 & 0 & 0.06 & 0 & $\mathrm{n} / \mathrm{a}$ & $\mathrm{n} / \mathrm{a}$ \\
\hline Nepal & $\mathrm{n} / \mathrm{a}$ & 0 & 0 & 27 & 83,000 & $3.6-6.2$ & 3,000 \\
\hline Pakistan & 17,550 & 324 & 33 & $\mathrm{n} / \mathrm{a}^{\mathrm{c}}$ & 59,000 & 5.3 & 24,000 \\
\hline Sri Lanka & $\mathrm{n} / \mathrm{a}^{\mathrm{d}}$ & 0 & 0 & 12 & 2,000 & $\mathrm{n} / \mathrm{a}$ & 25,000 \\
\hline Total & $\mathbf{1 0 8 , 9 6 1}$ & $\mathbf{6 , 1 8 6}$ & $\mathbf{9 5}$ & $\mathbf{2 2 3 - 2 3 2}$ & $\mathbf{3 4 9 , 0 0 0}$ & & \\
\hline
\end{tabular}

a Kilowatt hours per square meter per day.

b The United States Agency for International Development (USAID) and the Asian Development Bank (ADB) are funding the development of wind and solar power projects in Afghanistan [76].

c Pakistan has biomass and waste-to-energy resources that it is interested in developing [77]. 
d Natural gas reserves have been discovered in the Mannar Basin between India and Sri Lanka. The Sri Lankan government has expressed interest in extracting these resources but doesn't have any current plans to do so since the withdrawal of the Cairn Lanka company that was exploring extraction [76].

The region likely has geothermal resources as well but data on their extent is lacking. The geology of the region indicates that there should be extensive geothermal resources in both the Himalayan region as well as uplifted areas in the other countries [81]. However, there has been very little exploration to date, so the true extent of these resources is unknown. So far, assumptions about resources have depended on surface observation of hot springs rather than subsurface studies [81]. If significant resources suitable for geothermal power production are found, their exploitation could be included as part of a clean energy mandate (see Section 4.2.2) to reduce emissions from the power sector. However, depending on the technology used, geothermal power plants can emit gases, such as hydrogen sulfide, that can be harmful when inhaled [82].

Similarly, while biomass can in some circumstances be considered to be a renewable fuel, combustion of biomass produces air pollutant emissions of the same variety as solid and liquid fossil fuels - the exception being SOx, which generally is not present in biomass to the same extent as it is in coal or oil. This could be a concern for countries considering using biopower plants in the future, such as Nepal.

\subsection{Emissions Standards and Policy Options for Limiting Air Pollutants}

There are three broad categories of responses to emissions of atmospheric pollutants, each of which is described in much greater depth in the following sections:

- Section 2-Air quality standards that set limits on the atmospheric concentration of specific pollutants or set limits on pollutant emissions from a specific source.

- Section 3-Direct policies that require actions to directly regulate air quality (targeting emissions or emissions factor, as explained below).

- Section 4-Indirect policies that incentivize/disincentivize polluting activities, such as policies to encourage fuel switching or granting some generators preferential access to transmission.

Air quality standards for ambient air and point-source pollutants reflect a country's desired goals but don't accomplish air quality improvements without effective mechanisms to meet the standards. Direct and indirect policy instruments and regulations are necessary to move toward those goals.

Direct policies addressing air quality are those that limit air emissions from specific point sources. They can do that by putting a limit on mass emissions (E) or on the emission factor (EF, mass emitted per unit activity). The basic equation is:

$$
\mathrm{E}(\text { emissions in mass) }=\mathrm{EF} \times \mathrm{A} \text { (activity) }
$$

The direct air quality regulations discussed in this report regulate EF or E (i.e., cap E or limit EF) or constrain the operation of an emission source (e.g., limiting operating hours). 
Indirect policies modulate the use of different fuels or emission sources (the "activity"). Indirect policies incentivize/disincentivize an activity such as fuel switching (e.g., generating electricity with renewables vs. fossil sources). There are many more varieties of indirect policies than direct policies.

Although it certainly isn't a policy, it should be acknowledged that a substantial impact on air emissions comes from insecurity of supply in the power sector. Bhutan is the only country in the region with excess power generation capacity [34]. Despite plentiful energy resources, most countries in South Asia have insufficient generation, and regular outages have a detrimental impact on economic output and productivity. According to the South Asia Regional Initiative for Energy Integration (SARI/EI), one consequence of this is that consumers "are forced to invest in costlier diesel generators, which impact environmental sustainability while increasing the import burden of the countries" [34].

This policy scan identifies whether air quality policies and regulations exist, such as incentives for clean energy production and installation of pollution prevention technologies. It is much harder to ascertain whether a country implements actions to ensure compliance with regulations (e.g., monitoring, enforcement, fines) and thus this scan does not attempt such an assessment. The scan focuses on indirect policies because their impact can be more challenging to grasp and, consequently, they have not previously been investigated in much detail.

While this report focuses on policies that could influence emissions, it should be acknowledged that there are many other policies, regulations, economic practices, and infrastructure elements that need to be in place before air quality policies can be implemented. Dramatic expansion of electricity generation in a country requires a reliable grid regardless of the type of energy it carries, and countries with competitive electricity markets need a system for ensuring fair and transparent pricing in energy transactions and access to project financing.

Similarly, developing an interconnection standard for small generators on the distribution grid is a necessary prerequisite for adopting a net metering policy for renewable power. The net metering policy is addressed in this report because it can influence air pollution; interconnection is not addressed because it is one of many "emissions neutral" policies that, strictly speaking, do not influence air emissions themselves, but are a necessary underpinning for policies that do. 


\section{National Air Quality Standards that Set Pollutant Limits}

The first step in regulating harmful emissions is setting environmental standards. Concentration limits for pollutants of concern should be established to protect public health. Limits are set in the form of pollutant concentration limits averaged over a specified time period and are often referred to as national ambient air quality standards (NAAQS). NAAQS are often revised based on new evidence on health effects of different pollutants. Current NAAQS for various South Asian countries are provided in Table 2.

Table 2. Comparison of National Ambient Air Quality Standards (NAAQS) for South Asian Countries

(for reference, NAAQS are also shown for the United States)

\begin{tabular}{|c|c|c|c|c|c|c|c|c|}
\hline \multirow[b]{2}{*}{ Pollutant } & \multirow{2}{*}{$\begin{array}{c}\text { Averaging } \\
\text { Time } \\
\text { Period }\end{array}$} & \multicolumn{7}{|c|}{ NAAQS by Country } \\
\hline & & $\begin{array}{c}\text { Bangladesh } \\
{[7]}\end{array}$ & $\begin{array}{c}\text { Bhutan }^{a} \\
{[6]}\end{array}$ & $\begin{array}{c}\text { Indiab }^{\text {I }} \\
{[8]}\end{array}$ & Nepal & $\begin{array}{c}\text { Pakistan } \\
{[9]}\end{array}$ & $\begin{array}{c}\text { Sri Lanka } \\
\text { [12] }\end{array}$ & USA $^{c}$ \\
\hline \multirow{2}{*}{$\begin{array}{l}\mathrm{CO} \\
\left(\mathrm{mg} / \mathrm{m}^{3}\right)^{\mathrm{d}}\end{array}$} & 8 hours & 10 & 2 & 2 & 10 & 5 & 10 & 10 \\
\hline & 1 hour & 40 & 4 & 4 & & 10 & 30 & 40 \\
\hline \multirow{3}{*}{$\begin{array}{l}\mathrm{NO}_{2} \\
\left(\mu \mathrm{g} / \mathrm{m}^{3}\right)^{\mathrm{e}}\end{array}$} & 1 hour & & & & & & 250 & 188 \\
\hline & 24 hours & & 80 & & 80 & 80 & 100 & \\
\hline & 1 year & 100 & 60 & 40 & 40 & 40 & & 100 \\
\hline \multirow{2}{*}{$\begin{array}{l}\mathrm{O}_{3} \\
\left(\mu \mathrm{g} / \mathrm{m}^{3}\right)\end{array}$} & 8 hours & 157 & 100 & 100 & 157 & & & 137 \\
\hline & 1 hour & 235 & 180 & & & 130 & 200 & $235^{c}$ \\
\hline \multirow{2}{*}{$\begin{array}{l}\mathrm{PM}_{2.5} \\
\left(\mu \mathrm{g} / \mathrm{m}^{3}\right)\end{array}$} & 1 year & 15 & 40 & 40 & & 15 & 50 & 12 \\
\hline & 24 hours & 65 & 60 & 60 & 40 & 35 & 100 & 35 \\
\hline \multirow{2}{*}{$\begin{array}{l}\mathrm{PM}_{10} \\
\left(\mu \mathrm{g} / \mathrm{m}^{3}\right)\end{array}$} & 24 hours & 150 & 100 & 100 & 120 & 150 & 50 & 150 \\
\hline & 1 year & 50 & 60 & 60 & & 120 & 25 & \\
\hline \multirow{3}{*}{$\begin{array}{l}\mathrm{SO}_{2} \\
\left(\mu \mathrm{g} / \mathrm{m}^{3}\right)\end{array}$} & 1 hour & & & & & & 200 & 196 \\
\hline & 24 hours & 365 & 80 & 80 & 70 & 120 & 80 & $366^{c}$ \\
\hline & 1 year & 80 & 60 & 50 & 50 & 80 & & $78^{c}$ \\
\hline
\end{tabular}

a Bhutan's NAAQS has two separate standards-one for mixed-use areas and another for ecologically sensitive areas. NAAQS shown in the table are for mixed-use areas.

b India's NAAQS has two different standards based on land-use classification-(1) industrial, residential, rural, and other areas, and (2) ecologically sensitive areas (as identified by the central government). The concentration values shown in the table are for the first category.

c The U.S. Environmental Protection Agency (EPA) has revoked some standards, but those are still included in the table for comparison and marked with a superscript "c" in the USA column. Several U.S. EPA NAAQS concentrations are reported in parts per billion or parts per million; these were converted using standard conditions to $\mu \mathrm{g} / \mathrm{m}^{3}(1$ atmosphere pressure and $298 \mathrm{~K}$ temperature).

d Milligrams per cubic meter.

e Micrograms per cubic meter. 
While in most cases the concentration limits (NAAQS) serve as an additional motivator for emission reductions in addition to direct regulation of emissions, there are also cases where background concentrations are explicitly used to determine the maximum allowable emission rates from power plants. Geographical areas within a country that do not meet the concentration limits set by NAAQS are known as nonattainment areas, and governing agencies are typically expected to prepare plans to reduce the pollutant concentrations. These emission reduction measures could be applied to different sectors but, historically, the focus has been on mobile sources and point (or stationary) sources of pollution.

Electricity generation plants are large stationary pollution sources and are often required to meet emission standards for a variety of criteria pollutants using various emission control methodologies. The emission standards are often given in the form of mass of pollutant emitted per unit volume of flue gas. Emission standards for power plants burning various fuel types for South Asian countries are shown in Table 3. These emissions reduction methods from power plants often follow some or all of the approaches listed below:

1. Removal of pollutant species (e.g., sulfur, nitrogen) from raw fuel stream-includes precombustion steps, such as cleaning the fuel.

2. Process modifications to provide efficient combustion conditions.

3. Removal of pollutant after combustion - includes capturing the pollutant before it is released in the atmosphere. This can be further divided into three subcategories:

- Installing and maintaining control technology for capturing the pollutant released from fuel combustion.

- Limiting pollutant mass emitted from a polluting unit over a given time period.

- Enforcing pollutant-specific emission factors (emission rate per unit of production or fuel consumed).

These emission reduction regulations can be considered direct emission control policies because they directly control the mass of pollutants released into the atmosphere. There are also semidirect policies focused on improving power plant efficiencies, which indirectly reduce emission factors by increasing the EF's denominator (energy output). In the following section, we identify and discuss the policies based on the three methods (1-3), above, as well as policies to improve power plant efficiency.

Table 3. Emission Standards for Coal, Oil, and Natural Gas-Fired Power Plants Enacted Through Various Emissions Standard Regulations for 5 South Asian Countries ${ }^{a}$

\begin{tabular}{|c|c|c|c|c|c|c|}
\hline \multirow{2}{*}{ Country } & \multirow{2}{*}{ Fuel } & \multirow{2}{*}{$\begin{array}{c}\text { Capacity } \\
\text { Threshold (MW) } \\
\text { (if emission } \\
\text { standard varies by } \\
\text { plant size) } \\
\end{array}$} & \multicolumn{3}{|c|}{$\begin{array}{c}\text { Emission Standard } \\
\text { (micrograms per cubic meter, except as indicated) }\end{array}$} & \multirow{2}{*}{ Source } \\
\hline & & & PM & $\mathrm{SO}_{2}$ & NOx & \\
\hline \multirow[t]{2}{*}{ Bangladesh } & \multirow[t]{2}{*}{ Coal } & $<200$ & 350 & \multirow{2}{*}{$\begin{array}{l}\text { No emission standard; } \\
\text { instead, plants must have } \\
\text { minimum stack heights } \\
\text { of } 275 \mathrm{~m}(500 \mathrm{MW}), 220 \\
\text { m }(200 \mathrm{MW}-500 \mathrm{MW}) \\
\text { and emission rate-based }\end{array}$} & & \multirow[t]{2}{*}{ [71] } \\
\hline & & $\geq 200$ & 150 & & & \\
\hline
\end{tabular}




\begin{tabular}{|c|c|c|c|c|c|c|}
\hline \multirow{2}{*}{ Country } & \multirow{2}{*}{ Fuel } & \multirow{2}{*}{$\begin{array}{c}\text { Capacity } \\
\text { Threshold (MW) } \\
\text { (if emission } \\
\text { standard varies by } \\
\text { plant size) } \\
\end{array}$} & \multicolumn{3}{|c|}{$\begin{array}{c}\text { Emission Standard } \\
\text { (micrograms per cubic meter, except as indicated) }\end{array}$} & \multirow{2}{*}{ Source } \\
\hline & & & PM & $\mathrm{SO}_{2}$ & NOx & \\
\hline & & & & $\begin{array}{l}\text { stack height for plants } \\
\text { with capacity }<200 \mathrm{MW}\end{array}$ & & \\
\hline & \multirow[t]{3}{*}{ Gas } & $<200$ & & & 30 ppmb $^{b}$ & \\
\hline & & $200-500$ & & & 40 ppm & \\
\hline & & $\geq 500$ & & & $50 \mathrm{ppm}$ & \\
\hline Bhutan & $\begin{array}{l}\text { Coal, } \\
\text { oil, } \\
\text { wood }\end{array}$ & & 150 & 100 & 100 & [6] \\
\hline India & Coal & Any & 30 & 100 & 100 & {$[5]$} \\
\hline \multirow[t]{3}{*}{ Pakistanc } & Oil & Not specified & 300 & * & 600 & \multirow[t]{3}{*}{ [73] } \\
\hline & Coal & Not specified & 500 & * & 1200 & \\
\hline & Gas & Not specified & & 1700 & 400 & \\
\hline \multirow[t]{6}{*}{ Sri Lanka } & \multirow[t]{2}{*}{ Oil } & $25-100$ & 150 & $\begin{array}{l}\text { Fuel quality and stack } \\
\text { height }^{d} \text { based }\end{array}$ & $\begin{array}{l}550 \text { (steam } \\
\text { turbine); } 450 \text { (gas } \\
\text { turbine/ } \\
\text { combined cycle) }\end{array}$ & \multirow[t]{6}{*}[74]{} \\
\hline & & $\geq 100$ & 150 & $\begin{array}{l}850 \text { (for new plants, also } \\
\text { has daily cap on } \mathrm{SO}_{2} \\
\text { emissions), fuel quality- } \\
\text { based emission limits for } \\
\text { existing plants }\end{array}$ & $\begin{array}{l}500 \text { (steam } \\
\text { turbine); } 450 \text { (gas } \\
\text { turbine/ } \\
\text { combined cycle) }\end{array}$ & \\
\hline & \multirow[t]{2}{*}{ Coal } & $<50$ & 200 & 1600 & 750 & \\
\hline & & $\geq 50$ & 150 & $\begin{array}{l}850 \text { (for new plants, also } \\
\text { has daily cap on } \mathrm{SO}_{2} \\
\text { emissions), fuel quality- } \\
\text { based emission limits for } \\
\text { existing plants }\end{array}$ & 650 & \\
\hline & \multirow[t]{2}{*}{$\begin{array}{l}\text { Natural } \\
\text { Gas }\end{array}$} & $<50$ & 100 & 75 & $\begin{array}{l}350 \text { (steam } \\
\text { turbine); } 250 \text { (gas } \\
\text { turbine/ } \\
\text { combined cycle) }\end{array}$ & \\
\hline & & $\geq 50$ & 75 & 75 & $\begin{array}{l}300 \text { (steam } \\
\text { turbine); } 200 \text { (gas } \\
\text { turbine/ } \\
\text { combined cycle) }\end{array}$ & \\
\hline
\end{tabular}

a Data could not be obtained for Afghanistan, Nepal, or Maldives. (Nepal has no known major reserves of oil, gas, or coal to develop fossil-based power plants.)

${ }^{b}$ Parts per million. 
' Pakistan's national quality standards do not have a direct emissions limit for $\mathrm{SO}_{2}$. Instead, maximum allowable emissions are determined based on the background concentration of $\mathrm{SO}_{2}$ in three broad categories: 'unpolluted,' 'moderately polluted,' and 'very polluted.' Based on background, these emission standards take the form of maximum allowable daily emissions or maximum allowable increment to ground level concentration. In addition to the NOx emission standards listed above, there are also concentration-based emission limits so that annual mean NOx concentration does not exceed $100 \mu \mathrm{g} / \mathrm{m}^{3}$.

d See Section 3.5 for more on stack heights. 


\section{Direct Policies Intended To Reduce Air Pollution}

Environmental regulations can directly affect emissions of air pollutants from power plants. Direct policies addressing air quality are those that limit air emissions from specific point sources - in this case, fossil fuel power plants. Such policies put a limit on total mass emissions of a pollutant or on the emission factor (mass emitted per unit activity) and can be implemented by imposing a variety of constraints, such as limiting operating hours. This section provides examples of national policies and regulations that are intended to directly reduce air pollution from a country's power sector.

\subsection{Removal of Fuel Contaminants Before Combustion}

For coal, a process called coal beneficiation is employed to remove impurities — such as sulfur, ash, or other rocky material - extracted during mining. Coal from Indian mines can contain $30 \%-50 \%$ ash and other inert material. This can result in a myriad of problems - difficulty in pulverization, reduction in flame temperature, and excessive fly-ash generation containing unburned coal. Further, if the coal-burning power plants are far from pit heads, the transport of this coal (containing a large fraction of inert material) causes higher transportation-related emissions.

Policies that improve coal quality reduce the emissions associated with fuel combustion and, indirectly, also from transportation (because there is less mass shipped). Similar measures are also adopted to remove pollutants from other fossil fuels, such as removal of sulfur from natural gas or fuel oil to reduce related $\mathrm{SO}_{2}$ emissions. India has implemented a clean fuel regulation for coal (Table 4). However, Bangladesh has no fuel desulfurization policies despite its reliance on furnace oil and diesel for one-third of its electricity generation.

Table 4. India's Policy on Cleaning Coal To Reduce Emissions

\begin{tabular}{|l|l|l|}
\hline \multicolumn{1}{|c|}{ Measure } & \multicolumn{1}{|c|}{ Regulation } & \multicolumn{1}{c|}{ Brief Policy Description } \\
\hline Coal Beneficiation & $\begin{array}{l}\text { The Gazette of India } \\
\text { Notification G.S.R. 02 } \\
\text { (E), 2014 [13]. }\end{array}$ & $\begin{array}{l}\text { Requires the use of washed, blended, or } \\
\text { beneficiated coal in all stand-alone thermal power } \\
\text { plants of any capacity and captive thermal power } \\
\text { plants (with capacity of 100 MW or more) so that } \\
\text { ash content is restricted to 34\% on a quarterly } \\
\text { average basis. These measures not only help with } \\
\text { coal quality, but also reduce costs and emissions } \\
\text { associated with coal hauling from mines to the } \\
\text { plants. However, to meet energy demand through } \\
\text { the use of domestic coal during COVID-19, this } \\
\text { policy was relaxed through another gazette } \\
\text { notification provided relevant technology norms } \\
\text { were met and there were provisions for ash } \\
\text { management [14]. }\end{array}$ \\
\hline
\end{tabular}

\subsection{Combustion Process Modification To Reduce Emissions}

Some pollutant emissions can be reduced by modifying the combustion process to provide optimal conditions for fuel combustion. NOx, which is mostly emitted as NO, is primarily formed through two different mechanisms - thermal NOx (formed when nitrogen and oxygen 
molecules in air react with each other at high temperature) and fuel NOx (formed when the fuel contains organically bound nitrogen, which is the case with coal and oil) [83]. Combustion modification can control power plant NOx emissions, which limits NOx formation during the combustion phase. Combustion modification techniques include the following three methods for reducing NOx formation [1]:

- Reducing flaming zone peak temperatures - achieved by increasing the rate of flame cooling and decreasing the adiabatic flame temperature using dilution, using a fuel-rich flame zone.

- Reducing the residence time in the flaming zone - achieved by changing the shape of the flaming zone.

- Reducing the oxygen concentration in the flaming zone-achieved by controlling fuel-air mixing and decreasing excess overall air rates.

Some available combustion modification techniques are listed in Table 5 with their corresponding NOx reduction potential. These control techniques could work based on just one of the NOx reduction methods or a combination of them.

Table 5. Example Control Techniques Implemented for Combustion Process Modification To Reduce NOx Emissions [2, 10]

\begin{tabular}{|l|l|c|}
\hline \multicolumn{1}{|c|}{$\begin{array}{c}\text { Control Technique } \\
\text { (see Appendix A1 for description) }\end{array}$} & \multicolumn{1}{|c|}{ Abatement Principle } & $\begin{array}{c}\text { NOx Reduction Potential } \\
\text { for Coal-Fired Boilers }\end{array}$ \\
\hline Overfire air & Reduces peak temperature & $20 \%-30 \%$ \\
\hline Low NOx burners & Reduces peak temperature & $35 \%-55 \%$ \\
\hline Burner out of service & Reduces peak temperature & $10 \%-20 \%$ \\
\hline Air staging & Reduces residence time & $50 \%-70 \%$ \\
\hline Fuel staging & Reduces residence time & $50 \%-70 \%$ \\
\hline Low excess air & Reduces oxygen availability & $50 \%-70 \%$ \\
\hline
\end{tabular}

\subsection{Post-Combustion Controls To Reduce Emissions}

Post-combustion controls work by reducing the emissions after the pollutant is formed as a combustion by-product but before discharge to the atmosphere. Some pollutant-specific control technologies that are available are listed in Table 6. Once the control technologies are installed, they need to be monitored for performance and periodically inspected and maintained. Control equipment is often monitored and regulatory compliance is demonstrated through the use of automated systems, such as a continuous emissions monitoring system (CEMS), which reports emission rates of $\mathrm{SO}_{2}$ and $\mathrm{NOx}$. However, many countries do not have any CEMS-based reporting and also lack inspection and maintenance requirements, which can result in degradation in the performance of control equipment going undetected. 
Table 6. Available Control Technologies To Reduce Post-Combustion Emissions

\begin{tabular}{|c|c|}
\hline Pollutant & $\begin{array}{c}\text { Control Technology } \\
\text { (see Appendix A1 for description) }\end{array}$ \\
\hline $\mathrm{PM}_{2.5}$ and $\mathrm{PM}_{10}$ & $\begin{array}{l}\text { Electrostatic precipitators (ESPs) } \\
\text { Cyclones } \\
\text { Fabric Filters }\end{array}$ \\
\hline Sulfur oxides (SOx) & Flue gas desulfurization (FGD, dry and wet scrubbing methods) \\
\hline Nitrogen oxides (NOx) & $\begin{array}{l}\text { Selective catalytic reduction (SCR) } \\
\text { Selective noncatalytic reduction (SNCR) } \\
\text { SCR and SNCR are often used in combination with low-NOx } \\
\text { burners and over fire air burners }\end{array}$ \\
\hline
\end{tabular}

There are some country-specific policies on installation of post-combustion control technologies. The Government of India set emission standards for $\mathrm{PM}, \mathrm{SO}_{2}, \mathrm{NOx}$, and mercury in 2015, with the emission standards dependent on age and size of the units (see Appendix A2). Although most power plants in India are equipped with ESPs for removal of PM, there are no controls for $\mathrm{SO}_{2}$. Therefore, the 2015 regulations require most power plants to install FGD systems for removing $\mathrm{SO}_{2}$ from the exhaust stream. However, there was a setback to the implementation of these emission standards through a phased and rear-loaded implementation, with only $20 \%$ of coal plants required to meet the standard by 2020, and 40\% each in 2021 and 2022.

\subsection{More-Efficient Combustion Technologies To Reduce Fuel Consumption Per Unit of Energy Generated}

Coal power plants vary widely in their thermal efficiency, from an average of $36 \%$ (referred to as "subcritical"), to $45 \%$ ("supercritical"), and above ("ultrasupercritical"). Despite the maturity of the technology, many existing and recently constructed plants in Asia still use subcritical technologies, largely due to their lower capital cost, plus experience with the technology makes it less risky and easier for maintenance. However, in recent years countries have framed policies or made commitments to implement high-efficiency thermal technologies, the use of which reduces various combustion- and noncombustion-related air pollutants due to decreased coal fuel combustion per unit of energy produced. Some example policies or commitments include:

- In the run-up to the 2016 Paris Agreement, various countries submitted their intended nationally determined contributions (INDCs) — and, subsequently, nationally determined contributions (NDCs) - to reduce national emissions. India's 2016 NDC indicates a prioritization to move toward supercritical technologies for coal-based power plants [15].

- Bangladesh's conditional NDC and the national power plan mention that all new coal-fired power plants will use supercritical technology $[4,11]$.

\subsection{Higher Stack Height To Improve Pollutant Dispersion}

As height from the ground increases, the effect of drag resistance from ground elements (e.g., trees, buildings) decreases and wind speed increases. An increased wind speed causes greater dilution of pollutants. This increased dilution of emissions from point sources is often achieved by increasing stack heights. While directly meeting the emissions standard through control 
technologies is one way, increasing stack height often helps to meet the concentration-based emission standards, such as those for Pakistan where increment to background concentration is used as an emissions control measure. (Alternately, control technologies or a combination of control technologies and stack height can also be used.) Other countries specifically list the stack height requirement as part of the emission standard, such as Sri Lanka and Bangladesh (Table 3).

\subsection{Control of Pollutants Other Than PM, NOx, and $\mathrm{SO}_{2}$}

Pollutants other than those discussed earlier in this report can also result in the formation of secondary pollutants of concern. Ammonia contributes to the formation of secondary aerosols, whereas VOCs can contribute to the formation of ozone and secondary organic aerosols. While agriculture and animal husbandry remain its largest sources, power plants can also emit ammonia. Most of the power plant related ammonia is due to slip from NOx control devices (such as selective catalytic reduction). Regional agencies in the United States, such as the South Coast Air Quality Management District in California, have regulations that limit ammonia slip emissions. However, the authors did not find any such regulations for the South Asian nations. Similarly, power plants are not a big source of emissions for $\mathrm{CO}$ and VOCs, but their emissions can still be important. As for ammonia, the authors couldn't find any specific policies that control the release of $\mathrm{CO}$ and VOCs in the atmosphere for any of the South Asian countries. 


\section{Indirect Policies and their Effect on Air Emissions}

Environmental regulations can directly affect emissions of air pollutants from power plants; many types of policies and regulations can have an indirect effect on air pollution from power generation, sometimes including unintended effects. These policies and regulations may be local or national, may be enacted but unfunded or unimplemented, and may have a net positive or net negative impact on air pollutant emissions and concentrations. This section provides examples of policies and regulations that indirectly result in greater or lesser air pollution from a country's power sector.

\subsection{Policies and Regulations that Can Lead To Increased Emissions or Delay Emissions Reductions}

\subsubsection{Mandates, Financial, and Other Incentives for Combustion-Based Generation and Fuels}

Mandates and incentives that support the fossil fuel power industry can increase air pollution. Examples range from subsidies for domestic fossil fuel extraction to tax breaks for coal plants. In other cases, governments may specifically require power producers to use more-polluting fuels for economic or political reasons.

In Bangladesh, coal mine operators must build and run a $500 \mathrm{MW}$ or larger power plant at the mine mouth and sell the electricity to the domestic grid under a long-term power purchase agreement (PPA). They are also required to produce at least 3 million tons of coal annually [24]. These rules were implemented because the national government acknowledged that the public sector had not been able to develop energy resources and power plants fast enough and it needed to encourage coal-fired generation by private companies to meet national growth targets [24]. Historically, the country's power sector has been $90 \%$ dependent on natural gas, but its gas reserves are declining quickly and substantial coal reserves have been identified. The country has shown interest in building coal plants moving forward, which would increase air pollution compared to the gas plants [24]. However, in mid-2020, following the outbreak of COVID-19, Bangladesh government officials stated an interest in increasing the share of imported LNG in Bangladesh's energy mix, particularly as many of the coal construction projects experienced delays and cost increases, and Bangladesh's previous plans to significantly expand its coal-fired power generation came under international scrutiny from environmental groups [79].

Cutting subsidies to renewable generation has a similar effect on emissions as increasing subsidies for fossil fuel generation. India cut its renewable energy subsidies by $35 \%$ in 2019 to roughly US $\$ 1.5$ billion, reflecting a lower cost of renewables and also some protective policy decisions, such as including price caps in reverse auctions [56]. And the country still has very high coal subsidies: US\$2.3 billion in 2019 and could increase in the near future to support coal power plants with fitting pollution control equipment that must be installed by the end of 2022 (more on this in Section 4.1.3) [56]. There is also some debate as to whether the costcompetitiveness of grid-connected wind and solar power means that these two technologies no longer need subsidizing [56]. It is unclear whether these competing subsidies will increase or decrease the emissions from the electricity sector. 


\subsubsection{Constrained or Unavailable Cleaner Energy Resources}

If generation from clean energy supplies such as renewables and nuclear energy—or cleaner fossil fuel options such as natural gas instead of coal — are not available in sufficient quantity to meet demand, end users will inevitably have to use other, likely more polluting energy resources from either the grid or self-generation. This can delay emission reductions if people simply continue to use polluting sources, or it can actually increase emissions in certain circumstances, such as in rapidly growing economies where utilities have difficulty meeting escalating demand. Government policies regarding which energy resources to develop can influence these emissions.

Bangladesh has historically generated most of its electricity from domestic gas reserves. However, with electricity demand growing at an annual average of roughly $9 \%$, the national utility (Power Grid Company of Bangladesh) has not been able to keep up [25]. In 2014, total installed capacity was $10.6 \mathrm{GW}, 70 \%$ of which was cleaner-burning gas-fired plants [25]. But natural gas in Bangladesh is further constrained because it is needed to manufacture fertilizer and also run the country's fleet of compressed natural gas (CNG) vehicles [25]. When the government decided to start building LNG import facilities and new coal plants, which is not a speedy process, end users who needed a reliable source of electricity purchased more than $2 \mathrm{GW}$ of polluting portable generators running on diesel or fuel oil [25].

\subsubsection{Cost of Compliance with Air Quality Regulations}

Complying with air pollution regulations can be expensive, and without both financial support and a verification process, operators of polluting plants may try to postpone compliance for as long as possible, which delays any potential emissions reductions. This is exacerbated if a country tries to impose emissions regulations too quickly [49].

As an example, in 2015, India legislated new limits for SOx, NOx, particulate matter, and mercury emissions from coal plants. The International Institute for Sustainable Development estimated that it would cost the power sector US\$12 billion to comply with the new rules and would increase the average cost of electricity by $9 \%-21 \%$ per kilowatt-hour [49]. Existing plants were required to comply by December 2017. However, when that deadline passed and almost no coal plants had installed the pollution mitigation equipment due to the cost, the deadline for compliance was extended to 2022 [49].

\subsection{Policies and Regulations that Can Lead To Decreased Emissions}

\subsubsection{Electricity Trade Regulations}

Cross-border electricity trade (CBET) can enable countries to increase the financial efficiency of their power system operations by importing lower-cost electricity to offset fuel consumption in domestic power plants. Depending on the source of electricity imports, enabling policies for electricity trade can lower total air emissions and/or reduce local emissions impacts. CBET can also lead to economies of scale in investment, greater financing capability within the power sector, greater competition, and improved sector efficiency [29].

India and Bangladesh started trading electricity when they established a 500-MW-capacity link between them in 2013 [28]. Since then, India has also established bilateral electricity trade agreements and interconnections with Bhutan (1,146 MW) and Nepal (150 MW) [34], providing 
a nascent framework for expanding such cooperation to other South Asian countries. The region is rich in energy resources, yet each country experiences generation capacity shortages over the course of the year [33]. To help address this situation, negotiations are now ongoing between all eight countries in the South Asia region ${ }^{4}$ to cooperate on CBET, including discussions about a potential undersea cable linking India and Sri Lanka [31]. Table 7 provides an evaluation of prospects for CBET among five of the countries.

Successfully implementing CBET appears likely on balance to lead to reduced emissions of air pollutants in the region. In addition to addressing chronic electricity supply problems in each country, a primary impetus for a regional power trading agreement is to take advantage of the $349 \mathrm{GW}$ of hydropower capacity spread across the region (Table 1), much of which remains untapped due to a mismatch between the supply and local demand during the year. For example, Nepal has excess hydropower generation during the summer when electricity demand in northeast India is high, yet local power supplies are overtaxed [32]. However, in the winter, Nepal's hydropower resources are frozen and India's thermal (coal) power plants can help meet Nepal's demand, which would potentially increase the net air emissions during the winter season [34]. Upgrades to international and domestic transmission would enable greater use of clean energy, allowing hydropower to address daily and seasonal power imbalances across the region and offsetting or reducing some of the air pollution from conventional power plants.

In addition to infrastructure improvements, CBET requires the development of harmonized codes, policies, and regulations governing the power sector in each country [30]. Negotiations toward establishing regional development of CBET for SAARC is being supported by USAID through the SARI/EI, ${ }^{5}$ which is focused on strengthening energy security in South Asia [27].

SARI/EI is currently expanding its scope to include members of the Bay of Bengal Initiative for Multi-Sectoral Technical and Economic Cooperation (BIMSTEC), ${ }^{6}$ with a view to creating a power grid that would serve the entire region. BIMSTEC includes five SAARC members (Bangladesh, Bhutan, India, Nepal, and Sri Lanka), plus Myanmar and Thailand, with a combined total population of 1.6 billion people. There appears to be strong impetus behind this expansion because BIMSTEC members signed a memorandum of understanding in 2018 to cooperate on grid interconnection and, in 2020, SARI/EI and BIMSTEC held a joint conference to advance energy cooperation among the stakeholders.

\footnotetext{
${ }^{4}$ The eight countries covered by this report constitute the members of the South Asian Association for Regional Cooperation (SAARC), which was established in 1985 to collectively address several development-related issues, including electricity supply. https://www.saarc-sec.org/

${ }^{5}$ SARI/EI is a USAID initiative to strengthen energy security in South Asia. It was an expansion of the work conducted under its predecessor, the South Asia Regional Initiative for Energy, which USAID launched in 2000. https://sari-energy.org/about-sariei/background/

${ }^{6}$ https://bimstec.org/
} 
Table 7. Prospects for Cross-Border Electricity Trade in South Asia [31] ${ }^{a}$

\begin{tabular}{|c|c|c|c|c|c|}
\hline \multirow{2}{*}{$\begin{array}{l}\text { Importing } \\
\text { Countries }\end{array}$} & \multicolumn{5}{|c|}{ Exporting Countries } \\
\hline & India & Bhutan & Nepal & Bangladesh & Sri Lanka \\
\hline India & & $\begin{array}{l}\text { Significant } \\
\text { quantity of } \\
\text { hydro power }\end{array}$ & $\begin{array}{l}\text { Significant } \\
\text { hydropower } \\
\text { export } \\
\text { possible }\end{array}$ & $\begin{array}{l}\text { Significant amount } \\
\text { of gas or power } \\
\text { possible; resource } \\
\text { uncertain }\end{array}$ & $\begin{array}{l}\text { Some peak } \\
\text { power } \\
\text { support } \\
\text { possible }\end{array}$ \\
\hline Bhutan & $\begin{array}{l}\text { Dry season } \\
\text { support }\end{array}$ & & $\begin{array}{l}\text { Unlikely. } \\
\text { Similarity of } \\
\text { resources } \\
\text { and seasonal } \\
\text { shortages }\end{array}$ & $\begin{array}{l}\text { Small amount of } \\
\text { thermal power and } \\
\text { gas; connection via } \\
\text { India. }\end{array}$ & No scope \\
\hline Nepal & $\begin{array}{l}\text { Thermal power } \\
\text { support. Dry } \\
\text { season support. }\end{array}$ & $\begin{array}{l}\text { Unlikely. } \\
\text { Similarity of } \\
\text { resources } \\
\text { and seasonal } \\
\text { shortages. }\end{array}$ & & $\begin{array}{l}\text { Small amount of } \\
\text { thermal power and } \\
\text { gas; connection via } \\
\text { India. }\end{array}$ & No scope \\
\hline Bangladesh & $\begin{array}{l}\text { HVDC back-to- } \\
\text { back link. } \\
\text { Sharing } \\
\text { reserves; } \\
\text { electricity swap. } \\
\text { Some } \\
\text { hydropower; } \\
\text { connection via } \\
\text { India. }\end{array}$ & $\begin{array}{l}\text { Some hydro } \\
\text { power; } \\
\text { connection } \\
\text { via India. }\end{array}$ & $\begin{array}{l}\text { Some } \\
\text { hydropower; } \\
\text { connection } \\
\text { via India }\end{array}$ & & No scope \\
\hline Sri Lanka & $\begin{array}{l}\text { Dry season and } \\
\text { thermal power } \\
\text { support }\end{array}$ & $\begin{array}{l}\text { Unlikely } \\
\text { (far off) }\end{array}$ & $\begin{array}{l}\text { Unlikely } \\
\text { (far off) }\end{array}$ & Unlikely (far off) & \\
\hline
\end{tabular}

a See [32] for a table showing demand for electricity by month for these same five countries. The countries have complementary requirements because they have noncoincident demand peaks during the year.

Pakistan and Afghanistan are members of two other CBET initiatives. One of them is called TUTAP, which is the acronym for Turkmenistan, Uzbekistan, Tajikistan, Afghanistan, and Pakistan. One of the near-term goals of this planned transmission project is for Afghanistan to trade electricity with Pakistan, given that they have complementary needs: Afghanistan needs more electricity in the winter; Pakistan needs it in the summer [23]. The other CBET project is the Central Asia-South Asia (CASA-1000) ${ }^{7}$ regional power transmission corridor that is currently under construction and will facilitate the transfer of power between Tajikistan, Kyrgyzstan, Afghanistan, and Pakistan.

\footnotetext{
7 http://www.casa-1000.org/
} 
Afghanistan depends on imports to meet more than $60 \%$ of its electricity demand [20]. The Ministry of Energy and Water has pointed out that this situation limits its ability to control the energy mix on (and emissions from) its own power grid [21].

\subsubsection{Clean Energy Mandates}

Government targets that require increased use of renewables, nuclear power, and other sources of cleaner energy can reduce air emissions if they are legislated and implemented. However, such targets are often set based on total power plant capacity (in megawatts) rather than actual generation of electricity (in megawatt-hours); yet, only clean energy generation displaces generation from air-polluting sources, thus yielding air quality benefits. Unfortunately, clean energy mandates are often primarily aspirational and are not based on prior feasibility studies to determine if the mandated goal is financially and practically achievable. This category of indirect policies includes some climate-related targets because reducing GHG emissions from the electricity sector can also reduce atmospheric pollution.

Clean energy mandates have various names. The term "renewable portfolio standard" (RPS) usually refers to a capacity target, and the terms "renewable electricity standard" (RES) and "renewable quota" usually refer to generation or delivered energy targets, although the terms are sometimes used interchangeably. When codified in law and enforced with noncompliance penalties, an RPS/RES is one of the most effective policies for accelerating the adoption of cleaner renewable energy systems that can reduce emissions of air pollutants [46].

Afghanistan set a target of $95 \%$ of the projected total national power capacity of 5,000 MW to $6,000 \mathrm{MW}$ in 2032 to come from renewable sources through grid-connected, minigrid, and stand-alone projects [19]. Roughly 1,500 MW of the new capacity are expected to come from solar projects [40]. The Ministry of Energy and Water acknowledges that such rapid development means an initially heavy reliance on government and donor funding for projects but expects the renewable power industry to be led by the private sector by 2032 [20]. The ADB worked with the Afghan government to develop a Renewable Energy Roadmap for Afghanistan in 2017, which lays out what it says is a realistic plan for achieving this level of renewable generating capacity [20]. The Afghan government has repeatedly expressed a desire to increase its hydroelectric power capacity; however, a lack of transboundary water treaties with its neighbors, except Iran, prevents the World Bank and ADB from funding hydropower projects [76].

India has pledged that by 2030 it will reduce the emissions intensity of its GDP by $33 \%-35 \%$ from 2005 levels and have approximately $40 \%$ of its installed generating capacity use nonfossil resources [52]. It also set a goal of installing $100 \mathrm{GW}$ of solar photovoltaic (PV) capacity by 2022, partly funded by a tax on coal mining (more on this in Section 4.2.4) [51]. The country is aggressively pursuing this target. In 2019, India installed more solar PV than fossil generation and, by the end of the year, had deployed a total of $84 \mathrm{GW}$ of grid-connected renewable generation $[58,59]$.

In its 2019 Alternative and Renewable Energy Policy, Pakistan committed to getting 60\% of its electricity generation capacity from renewable sources by $2030-30 \%$ from hydropower and $30 \%$ from other renewables [66]. In addition to increasing the use of domestically available resources for power generation, reducing emissions of air pollutants was one of the drivers 
behind development of the policy, which notes that it would result in a more "environmentally friendly and affordable electricity mix compared to the heavily dominated mix of imported fossil fuels in the past." [66] However, implementation could be a major challenge. The policy depends on Pakistan expanding and upgrading its grid to integrate the country's hydropower capacity, which would be needed to compensate for the variability of the other renewable resources it is planning to develop [67]. Another challenge is that Pakistan is a country where regulation and oversight are mostly devolved to the provinces [68]. However, a recent World Bank report ${ }^{8}$ on variable renewable energy (VRE) in Pakistan offers some hope: "The 20 percent VRE target can be largely achieved by utilizing the 'low-hanging fruit' of spare capacity at existing substations, thereby avoiding the need for immediate grid upgrades ... Achieving the 30 percent VRE target will require some significant new investments, including new high-voltage transmission capacity to access the huge resource potential of Balochistan." [77]

By 2030, Nepal's NDC targets include expanding clean energy generation from approximately 1,400 MW to 15,000 MW, including generation from small-scale hydropower, solar, wind, and bioenergy plants [84]. Current energy demand satisfied by clean energy sources is well below $15 \%$ [84]. Nepal aims to: increase the quantity (in kilowatt-hours), quality, reliability, and affordability of electricity access from renewable sources; strengthen transmission and distribution links to support the scale-up of cooking, heating, and transportation using electricity; develop an enabling environment to provide power to small and midsize enterprises using distributed renewable energy generation sources; and promote public electric mobility through policy incentives, including subsidy policies and other financial mechanisms [80].

\subsubsection{Financial and Other Incentives for Power Generation from Clean Energy}

Subsidies and other policies that incentivize the use of renewable and other clean energy sources in the electricity sector can reduce air pollution. Examples range from preferential access to transmission lines to tax breaks for solar plants, although countries in South Asia appear to be leaning more heavily on the use of financial incentives.

A small financial sector with limited access to credit will constrain private sector development of renewable energy projects. It can also discourage foreign investment. In Afghanistan, for example, the current $15 \%$ bank loan rate is too high for local investors, and scarce access to finance is rated as one of the greatest obstacles to doing business in the country [40].

\subsubsection{Tax Incentives}

Common tax measures used to stimulate clean energy production around the world include lower corporate income taxes and a wide variety of incentives, such as an investment tax reduction based on the initial cost of a renewable energy system, a production tax incentive based on actual energy produced, property tax reductions for properties with renewable or energy efficiency technologies installed, elimination of sales and value-added tax for clean energy technologies (can be applied at scales from utility-scale generation to individual purchases of efficient

${ }^{8}$ http://documents1.worldbank.org/curated/en/883241610741226840/pdf/Main-Report.pdf 
appliances), reduced import taxes, and accelerated depreciation of renewable energy fixed assets [45].

India has a 10-year corporate income tax holiday for wind project developers [48]. Afghanistan provides a corporate income tax exemption for renewable energy project developers for the first 5 years of commercial operation to encourage expansion of the renewable sector [64].

Bangladesh exempts all power producers from corporate tax for 15 years but, because these are mainly using gas- and coal-fired plants, this tax exemption is unlikely to decrease air emissions [64].

By contrast, high taxes can hinder the purchase of renewable systems and any associated emissions reductions. Afghanistan has a very high import tax on PV systems simply because the value listed in the customs database has not been updated with new, lower prices; thus artificially inflating the cost of PV systems and discouraging switching to this lower-emissions technology [40].

While tax incentives are a relatively simple and highly flexible tool for stimulating the development of clean energy technologies, they are only of use to entities that have a tax burden-which means they do not financially benefit poor people, nonprofit organizations, or government agencies, for example [45].

\subsubsection{Direct Cash Incentives}

Direct incentives can have broader applicability because they can be accessed by entities without a tax "appetite." There are several variations on the theme. Rebates are typically provided after the purchase of an efficient appliance or renewable system; grants can be provided up front (e.g., to finance a feasibility study) or after a system is fully operational; and performance-based incentives are typically paid based on energy produced from a renewable energy system or saved by a whole-building energy efficiency upgrade [45].

In Afghanistan, donor and government grants dominate the renewable energy financing landscape but, in the long run, market mechanisms are a more efficient way to set prices. The country is beginning to experiment with hybrid financing models that could encourage the growth of this market sector. For example, for a recent $10 \mathrm{MW}$ Kandahar PV project, capital costs were covered by an up-front government grant but the PPA tariff that the national utility would pay the developer was decided using a reverse auction [20].

\subsubsection{Tradable Renewable Energy Certificates}

Legislative mandates for RES are one of the most effective policies for accelerating the adoption of renewable energy systems that can reduce the emission of air pollutants [46, 47]. A welldesigned RES includes an achievable clean energy target (discussed in Section 4.2.2) and some means to monetize the "green" benefits of lower pollution from the renewable generator, which makes it much easier to achieve the RES as the generator and end user do not need to be colocated. Such renewable energy credits (RECs) are defined as the environmental attributes of one megawatt-hour of renewable energy generation. Certified by third-party agencies, RECs can be traded, bought, and sold separately from commodity electricity, which allows a company located where renewable energy is not physically available to buy the RECs and claim that its electricity consumption is renewable [46, 47]. 
In South Asia, India is the only country that uses tradable renewable energy certificates. India introduced RECs in 2011 as a way to help states meet the country's overall renewable capacity targets. Those targets are set at the federal level but must be implemented by the states. The REC market allows states that are behind on meeting their renewable obligations to buy RECs from the states that are ahead of the curve and still allow them to achieve compliance [55].

RECs are typically designed for a single national electricity market (allowing people in one part of the country where there are no clean power plants to buy the RECs to offset less-clean power that happens to be available locally), but such a system could be set up within a single electricity trading area, such as the proposed South Asia CBET.

\subsubsection{Feed-In Tariffs}

A feed-in tariff (FIT) is a performance-based incentive that typically provides a fixed price per kilowatt-hour of electricity supplied. In some countries, FITs for renewable generators include other policy elements such as a guaranteed connection to the grid, a power purchase guarantee, and standardized power purchase contracts. Through guaranteed long-term fixed renewable electricity prices, FITs are one of the most effective tools to support increased investor confidence and expanded deployment of renewable energy [45].

As of 2019, only three countries in South Asia had FIT policies: Sri Lanka, India, and Pakistan [39].

Sri Lanka launched an updated FIT program in 2010. Wind, hydro, and biomass power plants are all eligible up to a capacity of $10 \mathrm{MW}$ per project. Developers have the option of selecting from two types of tariffs $[34,65]$ :

- Flat tariff-a fixed-price payment without inflation protection.

- Variable tariff - a complex track that varies the tariff with the price of the base fuel rate, operations and maintenance costs, and the year of operation. There is one tariff for years 1 to 8 , another for years 9 to 15 , and a third tariff for years 16 and above.

In addition to the feed-in tariffs, renewable project developers are given an additional boost because the Ceylon Electricity Board, the national utility, also has a fast-track standardized PPA for electricity generated from renewable energy sources [34].

Pakistan introduced a national FIT scheme for PV systems in 2014. The scheme was quickly amended in 2015 to increase the project capacity limit from $10 \mathrm{MW}$ to $100 \mathrm{MW}$, reduce the overall tariff payments, and implement different tariff rates in the north and south of the country [41].

India launched a comprehensive FIT scheme in 2009, covering all renewables (with varying capacity constraints) and using a cost-plus model for determining tariffs [42]. The tariffs were initially effective at spurring wind development but were only used once to issue a large-scale solar FIT. This was in Gujarat state in 2010, and the agreed tariff subsequently became so high relative to the prevailing price of electricity that Gujarat's utility tried to modify the agreement. The utility's efforts were rejected by the courts. Following this experience, others in India were reluctant to use FITs to procure large-scale solar PV and instead have shifted toward using competitive bidding processes [43]. The same thing eventually happened in the wind industry 
and by 2017 several Indian states stopped using FITs for wind energy procurement [44]. The primary role for FITs in India could be to finance residential and community solar and wind power on microgrids that are too small to be of interest to larger developers.

Afghanistan's Ministry of Energy and Water is currently designing a multilayered tariff structure aimed at encouraging the development of renewable energy and concomitant reduction in emissions without making it too expensive for project developers or electricity customers [19]:

- For grid-connected renewable energy projects - Tariffs are set on a "cost-plus" basis.

- For remote and off-grid renewable projects - Tariffs are set using "avoided cost of generation" in those cases where conventional generation would probably be significantly more expensive than renewable generation (because fuels would have to be transported), while making sure "that vulnerable communities are not burdened with high and unaffordable tariffs for basic and essential electricity services."

- For renewable-diesel hybrid projects-Tariffs are based on the replacement cost of diesel and/or prevailing tariffs, whichever is less.

\subsubsection{Net Metering and Net Billing}

Net metering and net billing policies both allow grid-connected end users to offset all or part of their power utility's electricity bill with electricity produced by on-site distributed generation (DG) systems. Most countries require that the DG system uses renewable resources, so this policy tends to reduce emissions. With net metering, the value of the electricity credits is typically at, or close to, the retail electricity rate. With net billing arrangements, the value of the electricity fed back into the grid is usually lower than the retail rate [45].

In Sri Lanka, the national net metering policy is open to all renewable energy systems with a generating capacity of up to $1 \mathrm{MW}$. The excess power sold to the grid is valued at the prevailing PPA rate and paid back to the user in the form of energy credits, with the user having flexibility about when to monetize them [20].

Maldives issued net metering rules in 2015, along with technical requirements for PV systems to connect to the grid [62].

In India, net metering is determined at the local level, not nationally, leaving a patchwork of regulations and creating uncertainty for those considering the long-term economics of selfgenerating renewable power. In 2019, for example, the Indian state of Goa promulgated its first net metering regulations, while the state of Uttar Pradesh cancelled prior net metering arrangements for all of its end users. New Delhi, however, expanded its PV net metering rules to include virtual net metering, which aggregates separate PV systems and treats them as a single generator for revenue purposes, giving a significant boost to the solar sector in that city [38].

\subsubsection{Financial Disincentives for Combustion-Based Generation}

Taxes and other policies that penalize the continued use of fossil energy sources in the electricity sector can reduce air pollution.

India has been disincentivizing coal-fired power generation since 2010 when it introduced a levy of 50 Indian rupees (INR) per tonne on all coal and lignite (a lower-grade "brown coal") mined 
or imported into the country [50]. The tax was increased again a couple of times after that and, in 2016, this "Clean Environment Cess" as it is officially known, was increased to INR 400/tonne (roughly US\$6/tonne) of coal, effectively increasing the price of coal by $30 \%$ [54]. The Cess is unofficially known as India's de facto carbon tax because receipts from the levy are used to support renewable energy projects and other environmental initiatives [50]. The country is also reducing subsidies on fossil fuels that could be used for home generation, including diesel and liquified petroleum gas (LPG) [52]. In 2003, the Indian government banned the importation of kerosene because it was being used to adulterate diesel fuel [53].

\subsubsection{Energy Conservation, Energy Efficiency Mandates, and Improvements}

Mandates requiring the use of more energy-efficient equipment outside of the electricity (power generation) sector may indirectly lead to a reduction in overall electricity use and, hence, a reduction in air pollutants. (By contrast, energy efficiency improvements to generation equipment used inside the electricity sector, such as a more efficient engine in a power plant generator set, reduces the consumption of fuel for a given power output, which in turn directly leads to a reduction in pollutants.) The following are examples of mandates leading to indirect reductions in pollutants.

Afghanistan has a long-term target of reducing electricity use by $100 \mathrm{GWh}$ and has identified the highest-impact priority areas to tackle first: a consumer awareness campaign, replacing incandescent bulbs in urban street lights with light-emitting diode devices, replacing electric water heaters/boilers with solar water heaters, improving the efficiency of large electric motors, improving the performance of building envelopes, and developing an Afghan energy services industry (energy service companies, or ESCOs) backed by a government accreditation and financing program [21].

The country is implementing its energy efficiency policy in two stages. The first stage (20172020) was focused on creating policies, standards, and the institutional infrastructure needed to support a domestic energy efficiency industry. For example, new buildings larger than 2,000 $\mathrm{m}^{2}$ must satisfy the Afghanistan Energy Efficiency Code for Buildings. In the second stage (20212032), Afghanistan will set up a financing method for efficiency projects and provide incentives for private industry to assume leadership in this sector [21].

To reduce the use of electricity for heating water, India has a target of installing $14 \mathrm{GW}$ (20 million $\mathrm{m}^{2}$ ) of solar hot water collectors by 2022 . The country is also working on demonstration projects for solar cooling in Gujarat State, both of which would reduce the demand for electricity and, hence, the emission of associated air pollutants [36].

Maldives has a goal of improving energy efficiency by 2030 and is making plans to incorporate a "Green Buildings" track into Bachelor and Master of Architecture programs offered by Maldives National University. In addition, the country has several consumer awareness efforts aimed at encouraging energy conservation [62].

Finding ways to reduce line losses in the electricity transmission and distribution (T\&D) system is a way to reduce overall emissions as a result of not wasting electricity, which is not quite the same as producing the electricity more efficiently. In terms of categorization, this is a bit of a grey area because the T\&D system is external to a power plant where efficiency improvements 
are typically made (and where direct policies take effect) and does not reduce the consumption of fuel for a given power output at the power station. However, T\&D system improvements do result in improved efficiency in the electricity delivery system with more electricity being delivered to the customer for a given power output at the power station. The effectiveness of this policy varies from country to country. In Afghanistan, for example, current T\&D line losses are approximately $23 \%$, compared to a global average of $9.5 \%$, and implementing efficiency improvements in this sector is expected to save roughly $15 \%$ of the country's electricity supply [21].

\subsubsection{Combined Heat and Power and District Heating/Cooling Requirements}

Central heating and cooling systems based on geothermal heat pumps or combined heat and power (CHP) plants can offset air emissions from lower-efficiency building and district heating and cooling (DHC) systems. Policies and regulations for central heat systems, including tariff policies, building codes, and heat distribution network requirements can indirectly reduce the air emissions from building and DHC systems, and CHP plants [36]. Note that, because district heating is usually mandated at the municipal level, many countries do not have national-level district heating policies.

Fossil fuels are still the primary resource used to heat and cool buildings, releasing harmful particulates and exacerbating air pollution. Today, only $10 \%{ }^{9}$ of the world's heating and cooling needs in buildings and industrial processes are supplied by renewable energy, largely due to a lack of supporting policies in these sectors [37]. Instead of developing and installing separate systems for HVAC needs and electricity generation, combining the two yields substantial efficiency gains, reducing the amount of electricity consumed and thereby indirectly reducing emissions of air pollutants.

India is the only country in South Asia with a CHP or DHC policy. India's Ministry of New and Renewable Energy has introduced a grant scheme for biomass cogeneration in industrial steam boilers with incentives paid out when the plant operates successfully [36].

DHC systems can easily use renewable resources but have traditionally used the heat from power plants or industrial processes burning coal or natural gas. In most cases, the systems that have switched to renewables have done so as a result of policy changes - and mostly in Europe. However, some DHC systems use biogas from sewage treatment plants and others use geothermal energy, either tapping into hydrothermal resources or using geothermal heat pumps [36].

\subsection{Other Policies and Regulations}

The following policies have a less predictable effect on emissions or are used somewhat differently in South Asia than in the rest of the world.

${ }^{9}$ See [37] for details: $10.4 \%$ of heating and cooling needs are met by "modern renewables" (i.e., excluding traditional biomass, nonrenewable electricity, and fossil sources). 


\subsubsection{Electricity Pricing and Tiered Rates}

Adjustments to electricity pricing, such as tiered rates or time-of-day rates, are becoming more prevalent. Such pricing, or simply high electricity prices in general, could shift individual behaviors to rely on energy sources that are likely to pollute more, such as portable generators, biomass cooking, and kerosene heaters. Such policies could thus lead to an unintended increase in air pollution from fossil energy sources in such cases. It is not known the fraction of consumers whom would react this way instead of reacting to time of use rates by shifting the timing of their electricity consumption, which is the intended policy effect.

Once it has improved energy access and implemented energy efficiency reforms, Afghanistan plans to consider "setting electricity pricing and tariffs to encourage actions to save energy" [21]. However, Afghanistan needs to tread lightly when developing such a policy because fuel switching from electricity to a more polluting energy source is a distinct possibility in a country where currently more than $97 \%$ of the rural population burn solid fuels (firewood, dung cakes, and crop residues) to meet their cooking and space-heating needs [21]. DABS, the national utility, charges four times as much for electricity delivered through off-grid PV projects than for grid electricity, and potential consumers have already demonstrated a reluctance to pay the higher prices [40].

Given the dramatic growth of renewable generation and comparable decline in use of coal-fired generation in India, capacity utilization at coal-fired plants has dropped from $70 \%-80 \%$ a decade ago to roughly $55 \%$ in $2019-2020$ [60]. This makes the plants less efficient and also more expensive to run, including the fact that their fixed costs have to be amortized over less generation. NPTC, a large power utility owned by the national government, is now making the case that time-of-day rates are necessary to justify investments in generating technologies, such as coal, that complement the variability of renewables [60].

\subsubsection{Energy Storage Mandates}

Energy storage is becoming more prevalent, using a variety of technologies such as batteries, pumped hydroelectric power, and other solutions. Energy storage enables greater penetration of variable renewable generation technologies; thus, policies that require or support storage can have the indirect effect of reducing air pollution from combustion sources - if storage does indeed increase the use of renewables via increased deployment (greater installed capacity) or greater utilization of renewable power generation (for instance, by constraining combustionbased generation). In other cases, replenishment of the energy storage device may come from fossil fuel plants run overnight or during daytime weather conditions unfavorable for renewable energy generation, which would increase air pollution. Implemented energy storage mandates also have the potential to reduce the use of, and need for, "peaker plants," which are typically fossil fuel power plants (often burning natural gas or fuel oil) that are run during times of peak demand. This would also reduce the emissions of pollutants from such power plants.

In its 2016 Power System Master Plan, Bangladesh proposed the use of energy storage systems to firm up intermittent wind and solar energy in both smaller off-grid renewable energy systems, instead of using the unreliable and polluting diesel generators that have been the norm, and larger grid-connected systems as a way to increase the penetration of renewables onto the grid. The plan proposes full-scale demonstration projects at both scales, using redox flow batteries for 
grid-connected systems. If implemented, this policy would reduce emissions of air pollutants because it is linked to increased use of renewables [26].

India has ambitious renewable generation targets and, according to the International Energy Agency, India will need more energy storage over the next 20 years than any other country, likely one-third of total global battery installed capacity by 2040 [58]. The country does not have an energy storage mandate per se, but its move away from baseload coal plants to variable renewable power plants requires an alternative energy source to balance the grid supply. In the absence of more extensive cross-border electricity trade or greater use of the country's hydropower resources, this is likely to mean greater use of utility-scale batteries.

Maldives is currently dependent on expensive, imported diesel generation. With falling prices in the renewable sector, the country is considering a shift to solar plus storage (likely batteries in the short term). In 2019, Maldives issued an Energy Storage Roadmap outlining the benefits of incorporating storage [61].

\subsubsection{Reliability Must-Run Agreements}

Certain power plants may be approaching scheduled retirement but may also be important for grid reliability. An agreement to keep an old power plant up and running for grid reliability purposes may have the deleterious effect of postponing air quality improvements that would result from replacing the power plant with new, cleaner technology.

Historically, must-run agreements were issued to coal or other baseload generation. But that is starting to change. Interestingly, in South Asia today, it is more often clean generators that are being placed in must-run status. Afghanistan, for example, has assigned must-run status to all of the renewable power plants in the country to maximize production and guarantee project developers that the national utility will buy all of the electricity they can generate [19]. Sri Lanka has done the same thing for some of its hydroelectric plants. In India, all renewable power plants with a capacity over $10 \mathrm{MW}$ (except biomass plants) and non-fossil-fuel-based cogeneration plants are treated as must-run [57]. Note that these must-run agreements are designed to maximize production, not maintain grid reliability. Must-run agreements for clean energy plants clearly reduce emissions of air pollutants, unlike must-run agreements for conventional power plants. 


\section{Key Findings and Future Work}

This report describes standards and policy instruments used in South Asia to reduce air pollution from fossil fuel combustion in the electricity sector and provides examples of countries that use those instruments. Time constraints meant that the authors were not able to analyze the effectiveness of the policies or investigate other important related issues, such as air pollution from the transportation sector and climate-related impacts from air emissions in the power sector.

The report includes examples of (1) policies that directly regulate air quality by limiting emissions from specific point sources (by restricting operating hours, for instance) and (2) indirect policies that incentivize or disincentivize polluting activities (such as policies to encourage fuel switching, for example).

With countries ranging in size from a remote island chain (Maldives) to an entire subcontinent (India), South Asia is certainly not a homogeneous region. Available energy resources, the condition and extent of national power grids, and degree of competition in the electricity sector vary widely. Such factors need to be considered when developing policies to tackle air pollution. Solutions that are helpful in one country are not necessarily appropriate in another. These conclusions present a couple of key observations noted during the authors' research; for information on the policy instruments unearthed, see Sections 3 and 4.

As mentioned in the Introduction, many countries are less focused on reducing air pollution and are more intent on providing electricity as a basic necessity for their citizens and as an engine of economic growth. Most countries are trying to do both, and Pakistan is a good example of this. It has ambitious renewable energy capacity targets of $60 \%$ installed by 2030 , yet also has an agreement with China to build seven more coal plants during the same period, as part of the China Pakistan Economic Corridor (CPEC), which will increase Pakistan's coal-fired generation capacity from 3\% in 2017 to $20 \%$ in 2025 [75]. According to a solar and wind developer in Pakistan, "A coal pipeline of around 4,000-5,000 megawatts will not provide much space for renewables" [75]. The current Pakistani government is focusing on the CPEC projects and is taking the approach of seeking private financing for all clean energy projects [66, 71].

Some countries are making good progress on emissions reduction by themselves, but others, including those where energy security is impacted by a mismatch between seasonal demand and resource availability, could benefit from expanded cross-border electricity trade (see Section 4.2.1). Easy access to the region's plentiful hydropower resources could enable pollution reduction across the region. One way to reduce air pollution from the electricity sector in South Asia would be to establish a regional power grid that links the Bay of Bengal Initiative for MultiSectoral Technical and Economic Cooperation, South Asian Association for Regional Cooperation, and Central Asia regions (through the CASA-1000 and TUTAP initiatives). This possibility is already being explored via discussions between some member countries. However, it is a challenging task because there also needs to be appropriate supporting legislation to make cross-border electricity trade possible. Each national legislature would need to develop and adopt a common set of technical and market regulations, standards, and rules that could support largescale cross-border electricity trading through a single grid linking South, Southeast, and Central Asia. 
On a smaller scale, there are substantial air pollution policy gaps in many countries across South Asia and providing technical assistance with development of both direct and indirect policies could help this region improve its air quality. Indirect policies are seldom recognized as opportunities to improve air quality, but the sheer variety of such policy instruments (see Section 4 for examples) allows for well-targeted outcomes and could increase their appeal if their potential efficacy in each country could be demonstrated. Further studies could quantify the air quality improvement and associated health benefits expected from implementation of specific policies. Other studies could potentially quantify the air quality improvements from integrating additional non-emitting renewables into the national grids. 


\section{References}

[1] Cooper, C. D.; Alley, F. C. Air Pollution Control: A Design Approach, Fourth.; Waveland Press: Long Grove, IL, 2010; https:/www.waveland.com/browse.php?t=380 (accessed Nov 29, 2020).

[2] U.S. EPA. AP-42: Compilation of Air Emissions Factors https://www.epa.gov/air-emissionsfactors-and-quantification/ap-42-compilation-air-emissions-factors (accessed Nov 17, 2020).

[3] Buckley, T.; Nicholas, S.; Ahmed, S. Bangladesh Electricity Transition: A Diverse, Secure and Deflationary Way Forward; Institute for Energy Economics and Financial Analysis, 2016; https://ieefa.org/wp-content/uploads/2016/11/Bangladesh-Electricity-Transition_-NOVEMBER2016.pdf.

[4] MoEF. Bangladesh's Intended Nationally Determined Contributions (INDC); Ministry of Environment and Forests (MOEF) Government of the People's Republic of Bangladesh, 2015; https://www4.unfccc.int/sites/ndestaging/PublishedDocuments/Bangladesh\%20First/INDC_2015 _of_Bangladesh.pdf (accessed Nov 16, 2020).

[5] MoEFCC. Environment (Protection) Amendment Rules, 2015 (The Gazette of India); 2015; p 5; http://www.indiaenvironmentportal.org.in/files/file/Moef\%20notification\%20-\%20gazette.pdf (accessed Jan 10, 2020).

[6] NEC. Environmental Standards, 2020; National Environment Commission, Royal Government of Bhutan, 2020; http://www.nec.gov.bt/necs/wp-content/uploads/2020/10/ES-2020_Web.pdf (accessed Nov 16, 2020).

[7] MoEF. National Ambient Air Quality Standard. Government of the People's Republic of Bangladesh, Ministry of Environment and Forest http://case.doe.gov.bd/file zone/reports publications/monthly reports/MonthlyReport_March_2013_REV1.0.pdf (accessed Nov 16, 2020).

[8] CPCB. National Ambient Air Quality Standards. Air (Prevention and Control of Pollution) Act, 1981. The Gazette of India; 2009; https://cpcb.nic.in/uploads/National_Ambient_Air_Quality_Standards.pdf.

[9] Pakistan EPA. National Environmental Quality Standards for Ambient Air. Pakistan Environmental Protection Act, 1997 http://www.mocc.gov.pk/moclc/userfiles1/file/MOC/National\%20Environment $\% 20$ Quality $\% 20 \mathrm{~S}$ tandards/NEQS\%20for\%20Ambient\%20Air.pdf (accessed Nov 16, 2020).

[10] U.S. EPA. Nitrogen Oxides (NOx), Why and How They Are Controlled; EPA 456/F-99-006R; Office of Air Quality Planning and Standards, United States Environmental Protection Agency: Research Triangle Park, NC, 1999; p 57; https:/www3.epa.gov/ttncatc1/dir1/fnoxdoc.pdf.

[11] Ministry of Power, Energy and Mineral Resources. Revisiting Power Sector Master Plan 2016; 2018; https://powerdivision.portal.gov.bd/sites/default/files/files/powerdivision.portal.gov.bd/page/4f81 bf4d $1180 \quad 4 \mathrm{c} 53$ b27c_8fa0eb11e2c1/Revisiting $\% 20$ PSMP2016\%20\%28full $\% 20$ report $\% 29$ sig ned.pdf (accessed Nov 16, 2020).

[12] MoENR. The National Environmental Act, No. 47 of 1980 (The Gazette of the Democratic Socialist Republic of Sri Lanka); 2008; 
http://www.cea.1k/web/images/pdf/airqulity/1562_22E\%20Ambient\%20air\%20quality\%20\%20english.pdf (accessed Nov 16, 2020).

[13] Ministry of Environment and Forests Notification. The Gazette of India. New Delhi, Jan 2, 2014. http://www.indiaenvironmentportal.org.in/files/file/beneficiated\%20coal.PDF (accessed Dec 4, 2020).

[14] Ministry of Environment, Forest and Climate Change Notification. The Gazette of India. New Delhi, May 2020. http://egazette.nic.in/WriteReadData/2020/219495.pdf (accessed Dec 8, 2020).

[15] India First NDC. NDC Registry, UNFCCC secretariat. Oct 1, 2016. https://www4.unfccc.int/sites/NDCStaging/pages/Party.aspx?party=IND (accessed Dec 1, 2020).

[16] World Bank Group. The Global Distribution of Air Pollution. 2019. License: Creative Commons Attribution (CC BY 4.0). https://datatopics.worldbank.org/world-developmentindicators/stories/the-global-distribution-of-air-pollution.html (accessed Dec 20, 2020).

[17] Health Effects Institute. 2019. State of Global Air 2019: A Special Report on Global Exposure to Air Pollution and its Disease Burden. Boston, MA. https://www.stateofglobalair.org/sites/default/files/soga 2019 report.pdf (accessed Dec 21, 2020).

[18] Ahady, S.; Dev, N.; Mandal, A. An Overview of the Opportunities and Challenges in Sustaining the Energy Industry in Afghanistan. E3S Web Conf. 2020, 173, 03006. https://www.e3sconferences.org/articles/e3sconf/pdf/2020/33/e3sconf icacer2020 03006.pdf (accessed Dec 20, 2020).

[19] Afghanistan Renewable Energy Policy, 2015. Ministry of Energy and Water. https://policy.asiapacificenergy.org/sites/default/files/Afghanistan-Renewable-Energy-PolicyEnglish-and-Dari.pdf (accessed Dec 21, 2020).

[20] Renewable Energy Roadmap for Afghanistan RER2032. Ministry of Energy and Water, Islamic Republic of Afghanistan. 2017.

https://policy.asiapacificenergy.org/sites/default/files/Renewable\%20Energy\%20Roadmap $\% 20 \mathrm{fo}$ r\%20Afghanistan\%20RER2032.pdf (accessed Dec 25, 2020).

[21] Afghanistan Energy Efficiency Policy. Ministry of Energy and Water, Islamic Republic of Afghanistan. 2016.

https://policy.asiapacificenergy.org/sites/default/files/Afghanistan $\% 20$ Energy $\% 20$ Efficiency $\% 20$ Policy\%20\%28Draft\%202016\%29.pdf (accessed Dec 25, 2020).

[22] Afghanistan: Investment Opportunities in Energy Sector. Kabul. Ministry of Energy and Water. 2017. https://main.dabs.af/uploads/tenders/83a9c8bde46af9c4a03499f6f566d5e6.pdf (accessed Dec 20, 2020).

[23] Country Energy Data [Select country; no unique URL] https://sari-energy.org/programactivities/cross-border-electricity-trade/country-energy-data/ (accessed Dec 20, 2020).

[24] Power System Master Plan. Government of Bangladesh. 2010. https://policy.asiapacificenergy.org/sites/default/files/PSMP2010 reduced.pdf (accessed Dec 25, 2020).

[25] EIA. International: Bangladesh. U.S. Energy Information Administration (EIA). https://www.eia.gov/international/analysis/country/BGD (accessed Dec 31, 2020). 
[26] Power System Master Plan. Government of Bangladesh. 2016. https://policy.asiapacificenergy.org/node/3219/portal (accessed Dec 31, 2020).

[27] Towards Regional Energy Security in South Asia. https://sari-energy.org/aboutsariei/background// (accessed Dec 20, 2020).

[28] Integrated Research and Action for Development (IRADe) https://irade.org/ > Energy \& Power Systems $>$ Publications [see abstract of Conference Proceedings; no unique URL] (accessed Dec $23,2020)$.

[29] BIMSTEC and SARI/EI jointly organize "Workshop on Enhancing Energy Cooperation in the BIMSTEC Region on 25-26 February." 2020. https://sari-energy.org/event/bimstec-and-sari-eito-jointly-organise-workshop-on-enhancing-energy-cooperation-in-the-bimstec-region-on-25-26february/ (accessed Dec 20, 2020).

[30] Policy Regulatory Framework For CBET. https://sari-energy.org/program-activities/policyregulatory-framework/ (accessed Dec 20, 2020).

[31] Cross Border Electricity Trade. https://sari-energy.org/program-activities/cross-border-electricitytrade/ (accessed Dec 20, 2020).

[32] CBET opportunities in SA. https://sari-energy.org/program-activities/cross-border-electricitytrade/cbet-opportunities-in-sa/ (accessed Dec 20, 2020).

[33] Formulation of model set of electricity regulations for implementation of the SAARC Framework Agreement for Energy (Electricity) Cooperation (SFAEC) and for advancing electricity trade in the SAARC countries. Integrated Research and Action for Development (IRADe). September 2018. https://sari-energy.org/wp-content/uploads/2019/04/Report-Formulation-of-Model-set-ofelectricity-regulations-for-implementation-of-the-SAARC-Framework-Agreement-for-EnergyElectricity-Cooperation-SFAEC.pdf (accessed Dec 27, 2020).

[34] Cross-Border Electricity Trade in South Asia: Key Policy, Regulatory Issues/Challenges and the Way Forward. 2016. https://sari-energy.org/wp-content/uploads/2016/03/CBET-Policy-

Regulatory-Issues-Challenges-and-the-Way-Forward-Background-Paper-Jan-2015.pdf (accessed Dec 28, 2020).

[35] Prospects of Regional Energy Cooperation and Cross border Energy Trade in the BIMSTEC region. 2020. SARI/EI and IRADe. https://sari-energy.org/wpcontent/uploads/2020/02/BIMSTEC-Background-Paper_February-2020.pdf (accessed Jan 3, 2021).

[36] Renewable Energy Policies in a Time of Transition: Heating and Cooling (2020). IRENA, IEA and REN21. 2020. https://www.ren21.net/heating-and-cooling-2020/ (accessed Dec 29, 2020).

[37] Widespread benefits at hand with renewables in heating and cooling, but needed policies are missing in action. REN21. 2020. https:/www.ren21.net/heating-and-cooling/ (accessed Dec 29, 2020).

[38] Policy Landscape, Renewables 2020 Global Status Report. IRENA, IEA and REN21. 2020. https://www.ren21.net/gsr-2020/chapters/chapter_02/chapter_02/ (accessed Dec 27, 2020).

[39] TABLE R11. Feed-in Electricity Policies, Cumulative Number of Countries/States/Provinces and 2019 Revisions. IRENA, IEA and REN21. 2020. https://www.ren21.net/gsr-

2020/tables/table_11/table_11/ (accessed Dec 29, 2020). 
[40] BSW-Solar, AREU, Eclareon. Enabling PV Afghanistan. 2017. https://www.solarwirtschaft.de/fileadmin/user_upload/report_enabling_pv_afg.pdf (accessed Dec $21,2020)$.

[41] IEA. Pakistan feed-in tariff for solar power https://www.iea.org/policies/5702-pakistan-feed-intariff-for-solar-power (accessed Jan 3, 2021).

[42] Runyon, J.; Ingram, E. India's 1.1 billion move to feed-in tariffs. Renewable Energy World. 2009. https://www.renewableenergyworld.com/2009/10/01/indias-1-1-billion-move-to-feed-intariffs/ (accessed Jan 3, 2021).

[43] Prateek, S. Feed-in tariffs to make a comeback in India for small solar and wind projects. 2018. https://mercomindia.com/feed-in-tariff-solar-wind// (accessed Jan 3, 2021).

[44] Saurabh. Several Indian states consider ending wind energy feed-in tariffs. 2017. https://cleantechnica.com/2017/06/23/several-indian-states-consider-ending-wind-energy-feedtariffs/ (accessed Jan 3, 2021).

[45] Financial Incentives: Policy Overview and Good Practices. Clean Energy Solutions Center. https://cleanenergysolutions.org/policy-briefs/financial-incentives (accessed Dec 29, 2020).

[46] Renewable Electricity Standards: Good Practices and Design Considerations. Clean Energy Solutions Center. https://cleanenergysolutions.org/policy-briefs/res (accessed Nov. 19, 2020).

[47] McDonnell, T. Apple is leading the charge to overhaul Taiwan's renewable energy market https:/qz.com/1897345/apple-is-overhauling-the-renewable-energy-market-in-taiwan/ (accessed Jan 3, 2021).

[48] India: Supporting Wind Power with Tax Incentives and Ensuring Project Sustainability https://cleanenergysolutions.org/policy-briefs/wind/india (accessed Sept 17, 2020).

[49] Vibhuti Garg, Balasubramanian Viswanathan, Danwant Narayanaswamy, Karthik Ganesan. India's energy transition: The cost of meeting air pollution standards in the coal-fired electricity sector. International Institute for Sustainable Development (IISD) and the Council on Energy, Environment and Water (CEEW). 2019. https://www.iisd.org/publications/indias-energytransition-cost-meeting-air-pollution-standards (accessed Dec 31, 2020).

[50] Chaturvedi, I. The 'Carbon Tax Package': An Appraisal of Its Efficiency in India's Clean Energy Future. Carbon clim. law rev. 2017, 10 (4), 194-201. https://www.jstor.org/stable/44134899?seq=1 (accessed Dec 31, 2020).

[51] Saurabh. India doubles tax on coal again https://cleantechnica.com/2016/03/04/india-doubles-tax$\underline{\text { coal/ }}$ (accessed Oct 18, 2020).

[52] India's Intended Nationally Determined Contributions submitted to the United Nations Framework Convention on Climate Change. https://www4.unfccc.int/sites/submissions/INDC/Published\%20Documents/India/1/INDIA\%20I NDC\%20TO\%20UNFCCC.pdf (accessed Oct 4, 2020).

[53] Kerosene ban. Down To Earth. 2003. https://www.downtoearth.org.in/news/kerosene-ban-13885 (accessed Jan 2, 2021).

[54] Cropper, M. Air Pollution, Environmental Regulation and the Indian Electricity Sector. IIEPNIPFP Conference. 2016. https://cpb-us- 
e1.wpmucdn.com/blogs.gwu.edu/dist/5/1304/files/2018/05/Cropper-India-Presentation-IIEPNIPFP-24zw9bh.pdf (accessed Dec 3, 2020).

[55] IEA. Renewable Energy Certificates system. https://www.iea.org/policies/4816-renewableenergy-certificates-system?q=feed $\% 20 \mathrm{in} \% 20$ tariff $\% 20$ india\&s=1 (accessed Jan 3, 2021).

[56] IISD. Mapping India's Energy Subsidies 2020: Fossil fuels, renewables, and electric vehicles. 2020. https://www.iisd.org/system/files/publications/india-energy-transition-2020.pdf (accessed Jan 4, 2021).

[57] Central Electricity Regulatory Commission. Terms and Conditions for Tariff determination from Renewable Energy Sources. 2017. https://policy.asiapacificenergy.org/node/3656/portal (accessed Nov 15, 2020).

[58] IEA. India is going to need more battery storage than any other country for its ambitious renewables push. 2020. https://www.iea.org/commentaries/india-is-going-to-need-more-batterystorage-than-any-other-country-for-its-ambitious-renewables-push (accessed Jan 4, 2021).

[59] Cheema, K. S. India 2020: Challenges and Opportunities; Himalaya Publishing House: New Delhi, India, 2016. https://www.iea.org/reports/india-2020 (accessed Jan 4, 2020).

[60] Buckley, T. Who Would Still Fund a New Coal Power Plant in India? Stranded Asset Risks Continue to Rise as Solar Deflation Continues. IEEFA. 2020. https://ieefa.org/wpcontent/uploads/2020/05/IEEFA Who-Would-Still-Fund-a-New-Coal-Power-Plant-inIndia_May-2020.pdf $($ accessed Jan 4, 2021).

[61] Executive Summary. Energy storage roadmap for the Maldives. 2019. http://documents1.worldbank.org/curated/en/340311572621106332/pdf/Executive-Summary.pdf (accessed Jan 4, 2021).

[62] Energy Policy Updates. Ministry of Environment and Energy. Republic of Maldives. 2016. https://www.unescap.org/sites/default/files/Maldives\%20-\%20PPT\%201.pdf (accessed Sept 16, 2020).

[63] ADB. Nepal energy sector assessment, strategy, and road map. 2017. https://www.adb.org/sites/default/files/publication/356466/nepal-energy-assessment-roadmap.pdf (accessed Nov 17, 2020).

[64] Compendium of Electricity Regulations of South Asian Countries: Volume 1 (Afghanistan, Bangladesh \& Bhutan). SARI/EI Project Secretariat. 2020. https://sari-energy.org/wpcontent/uploads/2020/03/Compendium-Vol-1.pdf (accessed Dec 17, 2020).

[65] Gipe, P.; Summary of Sophisticated Sri Lankan Tariffs, Renewable Energy World. 2011. https://www.renewableenergyworld.com/2011/10/07/summary-of-sophisticated-sri-lankan-tariffs/ (accessed Dec 29, 2020).

[66] Government of Pakistan, Alternative and Renewable Energy Policy 2019. 2019. http://www.aedb.org/images/Draft_ARE_Policy_2019_-_Version_2_July_21_2019.pdf (accessed Nov 12, 2020).

[67] World Wind Energy Association, "PRES2019 declaration: Pakistan achieving 30\% plus 30\% renewable energy by 2030," Oct 1, 2019. https://wwindea.org/blog/2019/10/01/pres2019declaration-pakistan-achieving-30-plus-30-renewable-energy-by-2030 (accessed Oct 20, 2020). 
[68] Personal communication with Anne Sackville-West, Energy Officer, U.S. Embassy Islamabad, Pakistan. October 2020 to March 2021.

[69] Key topics - Bureau of South and Central Asian Affairs https://www.state.gov/key-topics-bureauof-south-and-central-asian-affairs/ (accessed Jan 5, 2021).

[70] Coda Zabetta, E., Mikko Hupa, and Kari Saviharju. Reducing NOx Emissions Using Fuel Staging, Air Staging, and Selective Noncatalytic Reduction in Synergy. Industrial \& Engineering Chemistry Research 2005, 44 (13), 4552-4561. https://doi.org/10.1021/ie050051a (accessed Jan 28, 2021).

[71] EGCB. Environmental Impact Assessment (EIA) of World Bank Financed Siddhirganj 450mw Combined Cycle Power Plant (CCPP) Project Siddhirganj, Narayangaj. Annex V; Electricity Generation Company Of Bangladesh Limited (EGCB Ltd.): Dhaka, Bangladesh, 2010; http://documents1.worldbank.org/curated/pt/135511468198578278/pdf/E26370V10P1247110EI A0BD0Siddhirganj.pdf (accessed Nov 17, 2020).

[72] World Health Organization. WHO Global Urban Ambient Air Pollution Database (Update 2016). 2018. https://www.who.int/airpollution/data/cities-2016/en/ (accessed Jan 7, 2021).

[73] Pakistan EPA. National Environmental Quality Standards; 2010; http://www.environment.gov.pk/images/PDF/NEQS-Air-IndustrlGas.pdf (accessed Nov 17, 2020).

[74] Gazette of Sri Lanka. National Environmental Act No. 47 of 1980, The Gazette of the Democratic Socialist Republic of Sri Lanka; 2019; p 15; http://www.cea.lk/web/images/pdf/airqulity/212636 E.pdf (accessed Jan 27,2021).

[75] Pakistan Pushes Renewables_-but Coal Expansion Continues Too. Reuters. August 7, 2020. https://www.reuters.com/article/us-pakistan-renewables-climatechange-trf/pakistan-pushesrenewables-but-coal-expansion-continues-too-idUSKCN253311 (accessed Jan 3, 2021).

[76] Personal communication with Lanta V Spencer, Kabul, Afghanistan. March 2021.

[77] Personal communication with Donald McCubbin, Acting Director, Office of Energy, USAID, U.S. Embassy, Islamabad, Pakistan. March 2021.

[78] Personal communication with Luis G Salas, Colombo, Sri Lanka. March 2021.

[79] Personal communication with Anne N Sherman, Dhaka, Bangladesh. March 2021.

[80] Personal communication with Michelle Lorenzo, Kathmandu, Nepal. March 2021.

[81] Study on Geothermal Resources of South Asia. SAARC Energy Centre. December 2011. https://www.saarcenergy.org/wp-content/uploads/2017/12/2010-Study-on-GeothermalResources-of-South-Asia.pdf (accessed May 6, 2021).

[82] Geothermal Power Plants-Meeting Clean Air Standards. U.S. Department of Energy Office of Energy Efficiency \& Renewable Energy. https://www.energy.gov/eere/geothermal/geothermalpower-plants-meeting-clean-air-standards (accessed May 12, 2021).

[83] How is NOx Formed. Energy Solutions Center. http://cleanboiler.org/workshop/how-is-noxformed/ (accessed June 14, 2021). 
[84] Second Nationally Determined Contribution. Government of Nepal. 2020. https://www4.unfccc.int/sites/ndcstaging/PublishedDocuments/Nepal\%20Second/Second $\% 20 \mathrm{Nat}$ ionally $\% 20$ Determined $\% 20$ Contribution \%20(NDC)\%20-\%202020.pdf (accessed August 14, 2021). 


\section{Appendix A.}

\section{A.1 Brief Description of Emission Control Devices Referred To in This Report}

This section provides a brief description of the working principle of various methods and technologies used for lowering emissions of NOx and other pollutants as mentioned in Table 5 (Section 3.2) and Table 6 (Section 3.3) [1, 10, 70].

Electrostatic precipitators (ESPs) - A device used to remove fine particulate matter. ESPs use the principle of ionization of the contaminated flue gas and a subsequent capture of charged particles by oppositely charged plates (collecting electrodes). ESPs are highly efficient, with efficiency reaching as high as $99 \%$.

Cyclones-Cyclone separators use the centrifugal and inertial forces to remove and capture particulate matter from flue gas. Based on design specification, cyclones can be used to capture larger particles $\left(\mathrm{PM}_{10}\right)$ as well as fine particles $\left(\mathrm{PM}_{2.5}\right)$. Though the efficiency of these devices depends on specific design parameters and use conditions, they are more effective in removal of particles with relatively larger aerodynamic diameters.

Fabric filters - Capture the dry particles in flue gas by using a filter bag. The fabric does some filtration, but the accumulated dust is also an important particulate removal medium.

Flue gas desulfurization (FGD) - Uses chemical scrubbing to remove sulfur dioxide from the flue gas. Given that $\mathrm{SO}_{2}$ gas is acidic, an alkaline scrubbing agent (e.g., limestone) is often used to remove $\mathrm{SO}_{2}$ from flue gas. Some $\mathrm{SO}_{2}$ removal processes are regenerative, where the removed $\mathrm{SO}_{2}$ is recovered as a useful product, whereas others are throwaway processes.

Selective catalytic reduction (SCR) - A very efficient NOx control device. In an SCR-based NOx control, ammonia is used to chemically break down NOx into nitrogen $\left(\mathrm{N}_{2}\right)$ gas and water vapor. The SCR catalyst used more efficiently facilitates the chemical reaction of ammonia with NOx. Efficiency of SCR is generally dependent on the temperature of exhaust gas, and ammonia slip is also an issue. SCR and SNCR are often used in combination with low-NOx burners and over fire air burners.

Selective non-catalytic reduction (SNCR) - The working principle of SNCR is similar to SCR, except that the catalytic agent is absent. However, due to several practical reasons, this often results in lower removal efficiency of NOx. SCR and SNCR are often used in combination with low-NOx burners and over fire air burners.

Overfire air burners - In this technique, the fuel is combusted in two or more stages. The primary flame zone is fuel rich and the following flame zones are fuel lean. This results in oxygen-deficient zones of partial combustion, resulting in lower temperatures and thus lower NOx formation.

Low NOx burners - In low NOx burners, NOx formation is inhibited by controlling the mixing of air with fuel, with a subsequent reduction of the peak flame temperatures. Reduced flame temperatures result in reduced NOx formation from combustion. 
Burner out of service - When multiple burners are used, oftentimes some 'burners are kept out of service' (i.e., they are not fed with fuel, but used for supplying air or flue gas). This results in a staged combustion with lower temperature compared to the temperature when all the burners are in service, thereby reducing the amount of NOx produced.

Air staging - As the name implies, the combustion is staged by dividing air into two different streams. The first stream is mixed with fuel such that the net result is a reducing flame (that is, with low oxygen content); the second stream, which has slightly excess air (compared to the fuel-air stoichiometric ratio), is injected downstream. NOx formation in this method is controlled by limiting the availability of $\mathrm{O} 2, \mathrm{O}$ and radicals $(\mathrm{OH})$.

Fuel staging - In this method, combustion is staged using fuel instead of the air (as in the 'air staging' method above). In the first stream used for primary combustion, the conditions are reducing (low oxygen), and the second stage of combustion is slightly oxidizing. Excess fuel in the primary combustion stage reduces the peak temperatures and the downward stream oxidizes the fuel while reducing $\mathrm{NOx}$ to $\mathrm{N}_{2}$.

Low excess air-Excess air denotes the air above the stoichiometric requirement and was used to achieve good fuel combustion. Owing to less-than-ideal fuel-air mixing, some excess air is always used. A few decades ago, the excess air used could be as much as 50\%-100\%; however, with rising fuel prices, this was reduced to $15 \%-30 \%$ (which was a practical limit to achieve good combustion). However, EPA research indicated reduction of NOx formation potential when the amount of excess air is lowered and thus subsequently low excess air started being used as a NOx control measure.

\section{A.2 Emissions Standards Set by the Government of India in 2015}

Table 8. New Emission Standards for Power Plants Enacted through the Environment Protection Amendment Rules, 2015 [5]

\begin{tabular}{|c|c|c|c|c|}
\hline \multirow{2}{*}{ Unit Installation Date } & \multicolumn{4}{|c|}{$\begin{array}{l}\text { New Emission Standard }\left(\mathbf{m g} / \mathrm{Nm}^{3}\right) \text { by Unit Capacity } \\
\text { (if applicable) }\end{array}$} \\
\hline & $\mathbf{P M}^{\mathbf{a}}$ & $\mathrm{SO}_{2}$ & $\mathrm{NO}_{\mathrm{x}}$ & Mercury \\
\hline Dec. 31,2003 , or earlier & 100 & $\begin{array}{l}600(<500 \mathrm{MW}) \\
200(\geq 500 \mathrm{MW})\end{array}$ & 600 & $\begin{array}{c}0.03 \\
(\geq 500 \mathrm{MW})\end{array}$ \\
\hline Jan. 1, 2004 - Dec. 31, 2016 & 50 & $\begin{array}{l}600(<500 \mathrm{MW}) \\
200(\geq 500 \mathrm{MW})\end{array}$ & 300 & 0.03 \\
\hline Jan. 1,2017 , or after & 30 & 100 & 100 & 0.03 \\
\hline
\end{tabular}

a Before the Environment Protection Amendments Rules, 2015, emission standards for only PM were in place with $350 \mathrm{mg} / \mathrm{m}^{3}$ for units $<210 \mathrm{MW}$ and $150 \mathrm{mg} / \mathrm{m}^{3}$ for units $>210 \mathrm{MW}$ [5]. 